
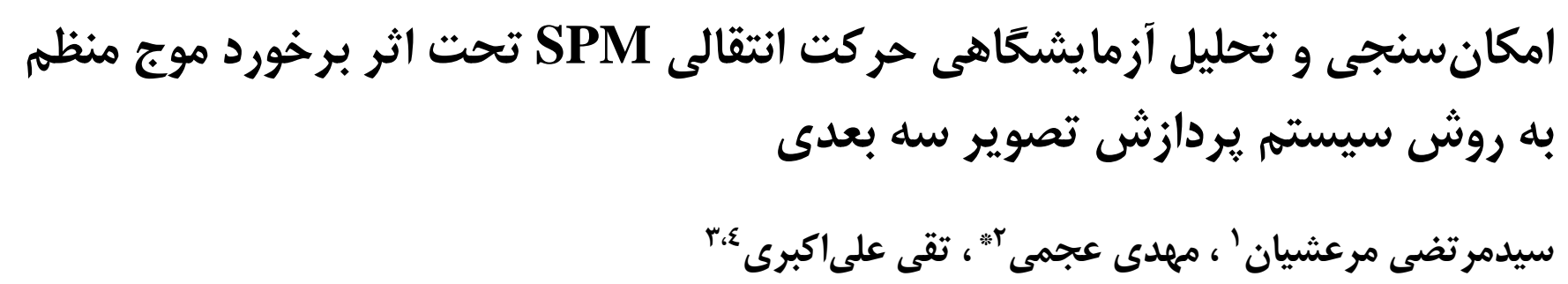

' ' كارشناسى ارشد، كروه مهندسى آب و محيط زيست، دانشكده مهندسى عمران دانشكاه صنعتى شاهرود؛ shahroodut.ac.ir '

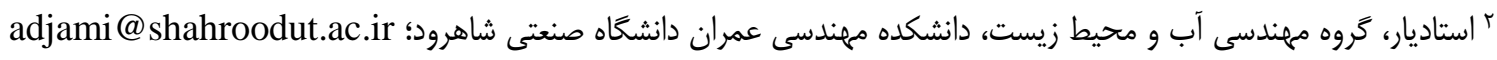

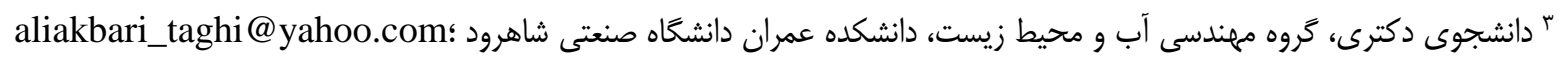

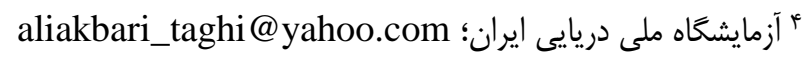

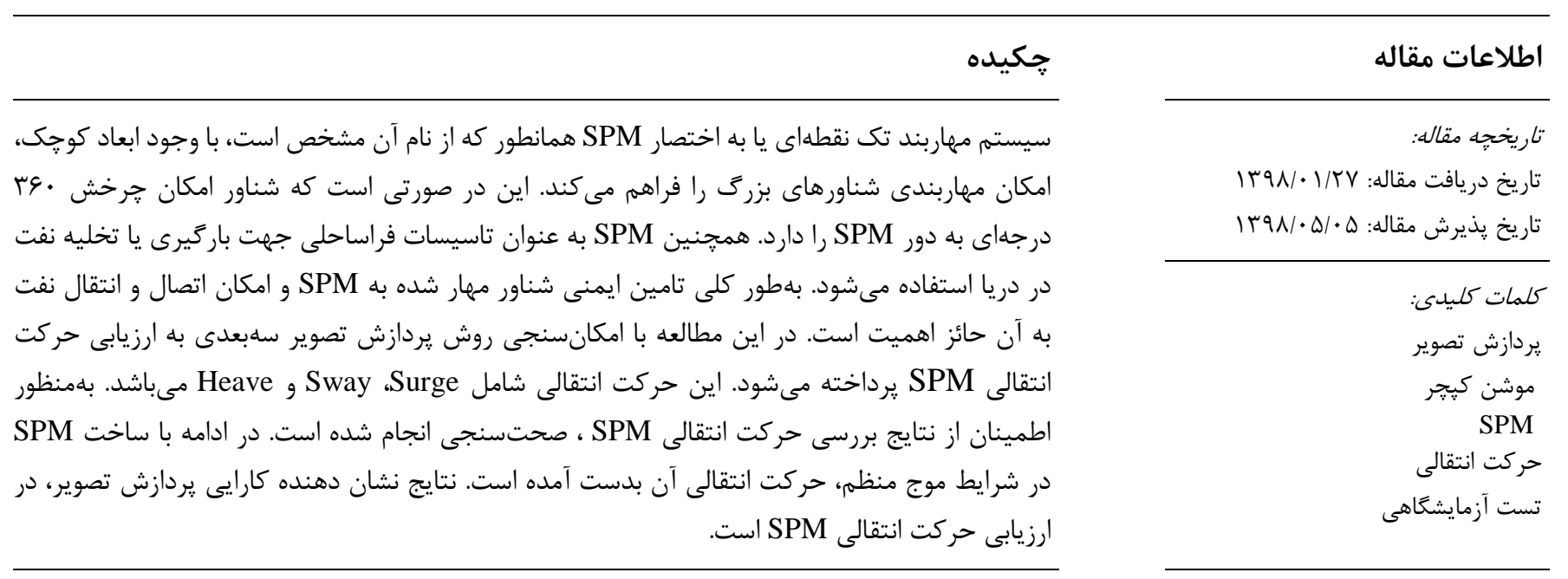

\title{
Feasibility and Experimental Analysis of SPM Translational Motion under the Effect of Regular Wave Using the 3D Image Processing System
}

\author{
Seyed Morteza Marashian", Mehdi Adjami2*, Taghi Aliakbari ${ }^{3,4}$ \\ ${ }^{1}$ MSc, Water and Environmental Engineering Department, Faculty of Civil Engineering, Shahrood University of Technology; \\ morteza.marashian@shahroodut.ac.ir \\ ${ }^{2}$ Assistant Professor, Water and Environmental Engineering Department, Faculty of Civil Engineering, Shahrood University of \\ Technology; adjami@shahroodut.ac.ir \\ 3 Ph.D. student, Water and Environmental Engineering Department, Faculty of Civil Engineering, Shahrood University of \\ Technology; aliakbari_taghi@yahoo.com \\ ${ }^{4}$ National Iranian Marine Laboratory; aliakbari_taghi@yahoo.com
}

\section{ARTICLE INFO}

Article History:

Received: 16 Apr. 2019

Accepted: 27 Jul. 2019

\section{Keywords:}

Image Processing

Motion Capture

SPM

Translational Motion

Experimental Test

\begin{abstract}
Single point mooring terminals are, as the name implies, facilities of small horizontal dimensions, to which large vessels are moored by means of a bow hawser or by any other means which allows the vessel to rotate 360 around the mooring point. Generally, the single point mooring terminal can have two functions. Primarily, it affords a safe mooring to the vessels. Secondly, it can form a link in the chain for the transport of oil. In this study, with the feasibility of 3D image processing, the SPM translational motion is evaluated. This translational motion includes Surge, Sway, and Heave. In order to ensure the results of the analysis of SPM translational motion, verification is carried out. In the following, by constructing SPM and situating it in reaction condition with regular wave, translational motion is obtained. Finally, the results indicate that image processing is acceptable in translational motion assessment of SPM.
\end{abstract}




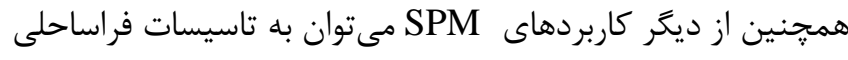
جهت باركيرى يا تخليه نفت در دريا اشـاره كرد. با توجه به كارئ كاربرى

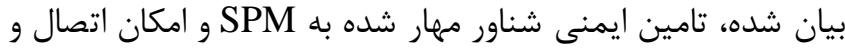

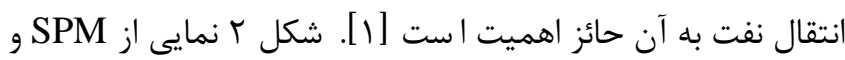

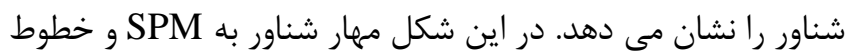
انتقال نفت مشخص شده است.

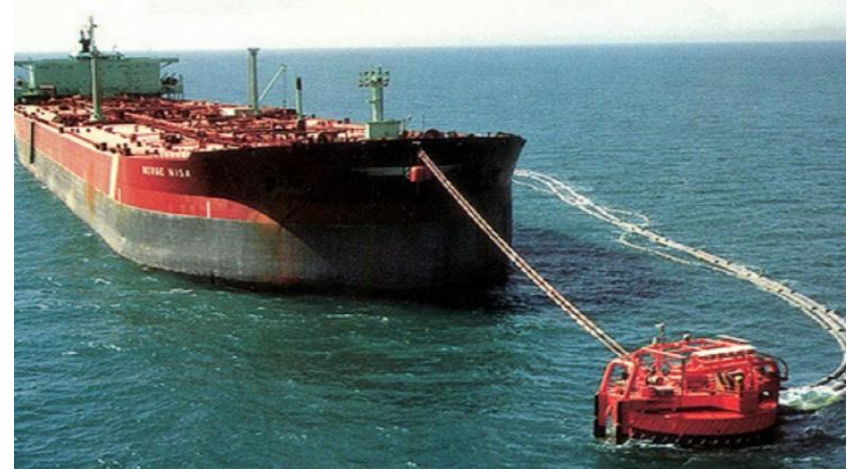

شكل r - نمايى از SPM و شناور به همراه خطوط انتقال نفت و مهاربندى [ب]

\section{r-1- بردازش تصوير}

يردازش تصوير به طور كلى، به برر سى تصاوير و ا ستخراج داده از

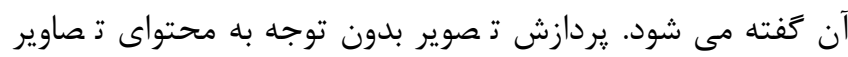

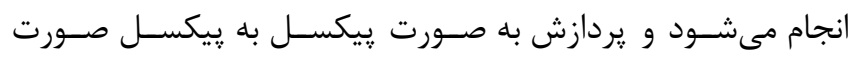
مى كيرد. در اين مطالعه براى بدست آوردن حركت انتقالى SPM از

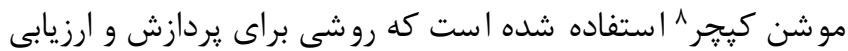

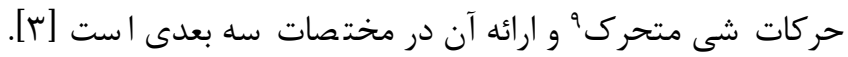
امكان رصــد دامنه حركات نامحدود شـى مورد بررسـىى، از مزاياى

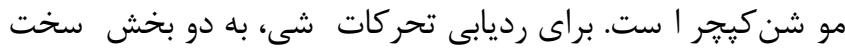

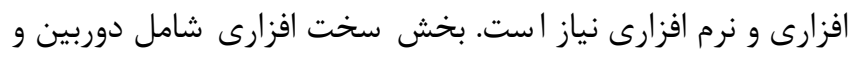

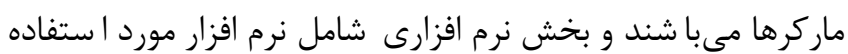

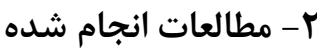

در اين بخش به معرفى مطالعات صورت كرفته در زمينه موشن كيجر

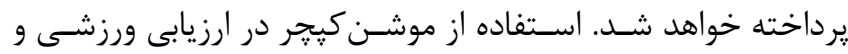

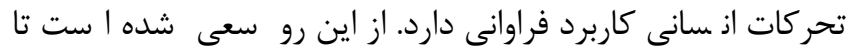

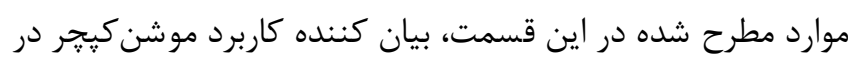

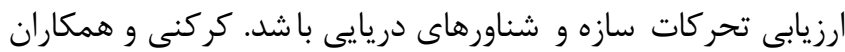

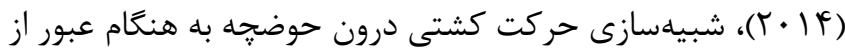

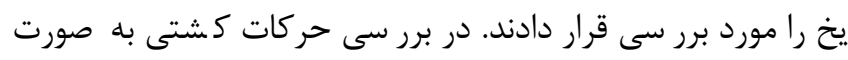

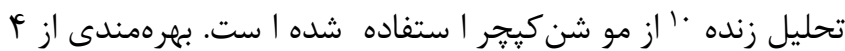

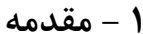

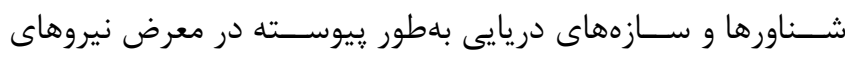

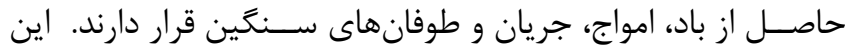

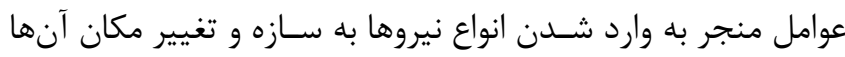

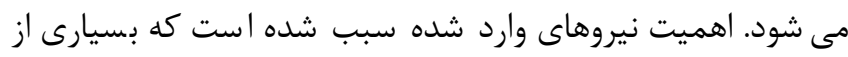
سازههاى دريايى با در نظر ترفتن ضرايب ايمنى بالا طراحى شوند

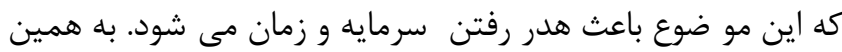

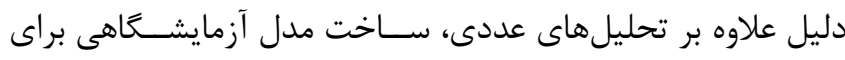
شناسايى رفتار سازه توصيه مى شود. با اندازهخيرى دقيقتر تغيير هكان ها و نيروهاى وارد بر ســــازه درد

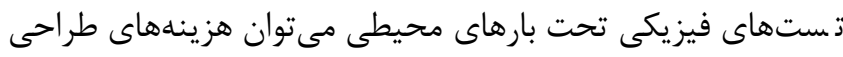

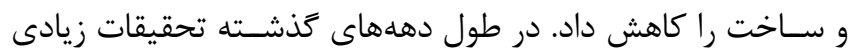

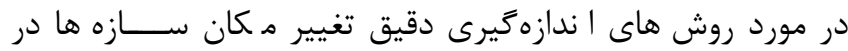
تستهاى آزمايشكاهى انجام شده است. در گروهى ازئ از اين تحقيقات،

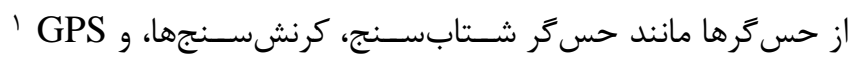
استفاده شده است. اين ابزارها داراى معايبى ازجمله مشكلات ندات نصب،

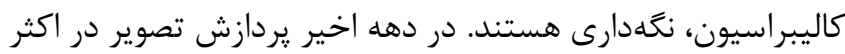

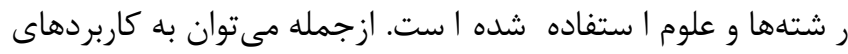

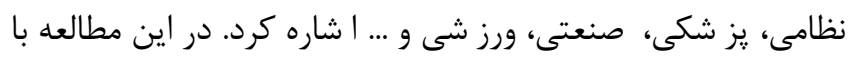

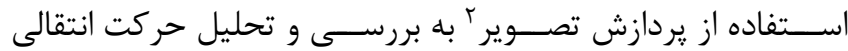

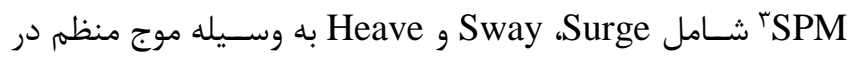

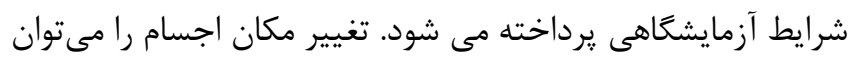

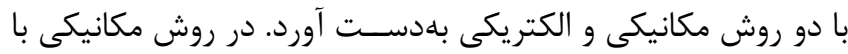

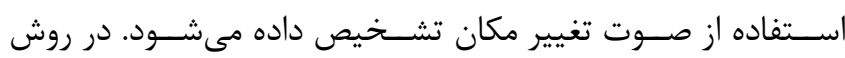

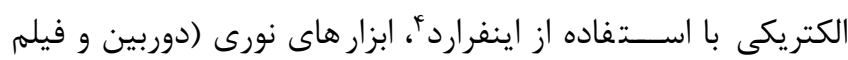

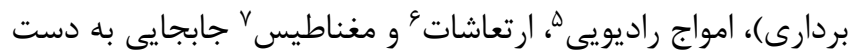

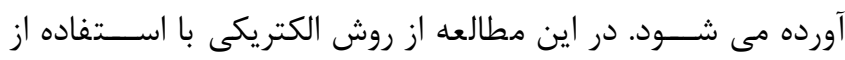

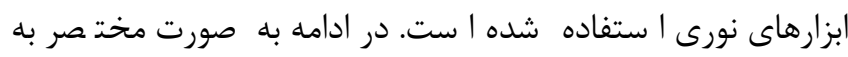

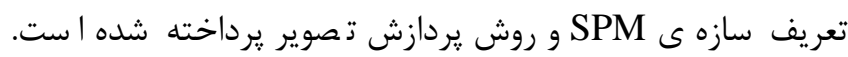
شكل ا نمايى شماتيك از SPM را نشان مىدهد.

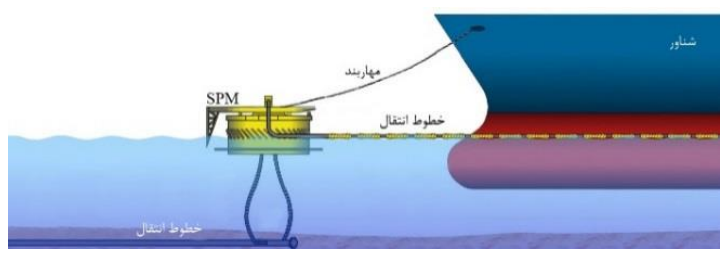

شكل ا - نمايى شماتيك از SPM و شناور هنعَام انتقال نفت

SPM -1-1

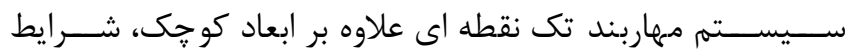

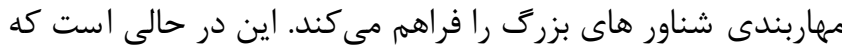

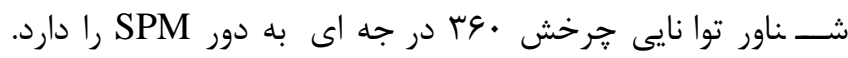




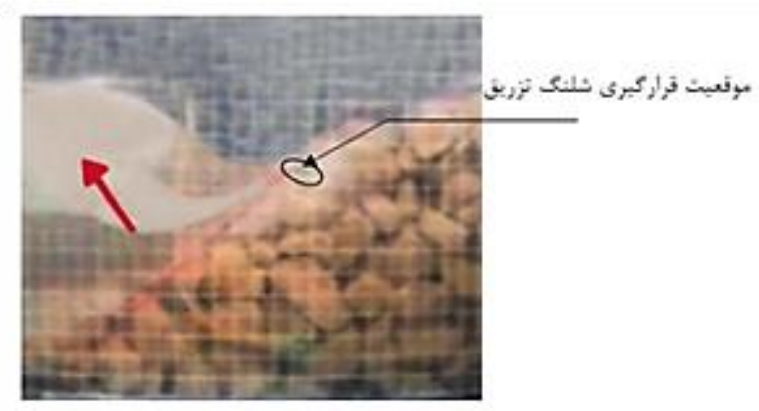

شكل ه - جهت حركت ماده تزريقى سفيد رنگ در هنگًام بيشترين تراز

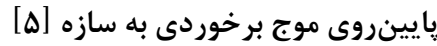

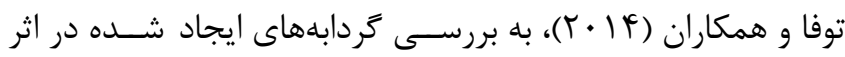

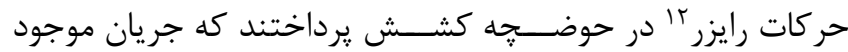

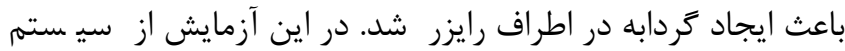
يردازش تصــوير شــركت كواليســيس براى اندازهذيرى يارامترهاى

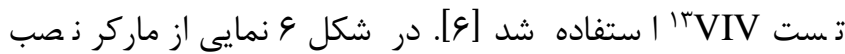

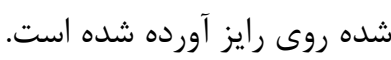

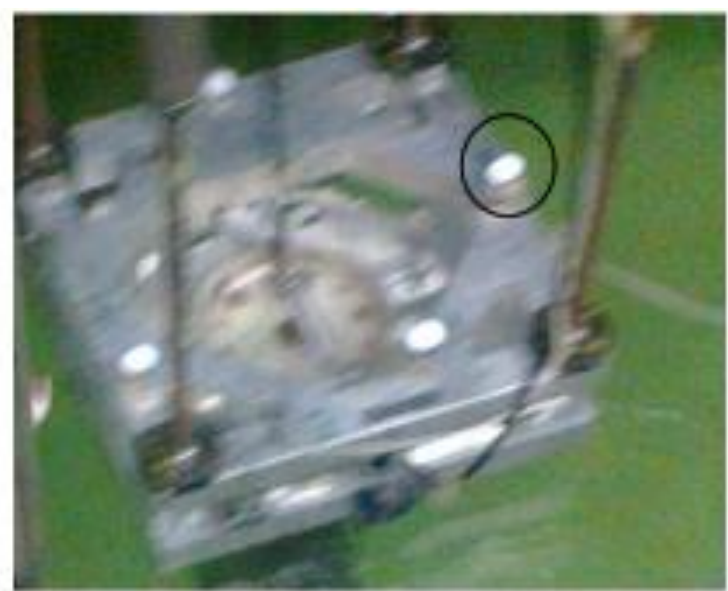

شكل 9 - ماركر روى رايزر براى سيستم يردازش تصوير كواليسيس [ع]

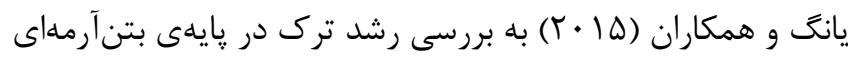

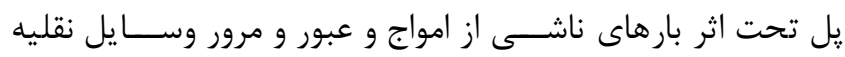

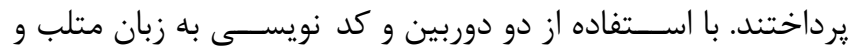

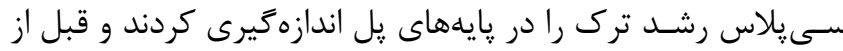

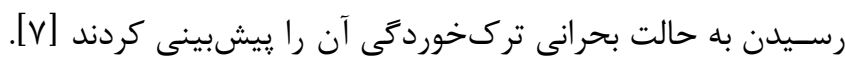
در شكل V نمايى از يايه بتن آرمه يل قابل مشاهده است.

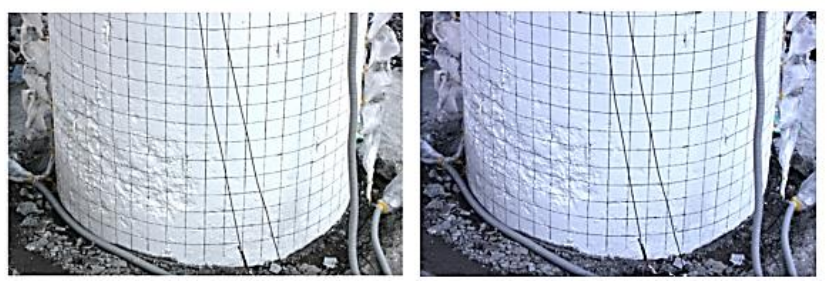

شكل V - تصاوير دو دوربين نصبشده براى بررسى رشد ترك [V]
دوربين و f ماركر را مى توان به عنوان بخشــى از ســـت افزار

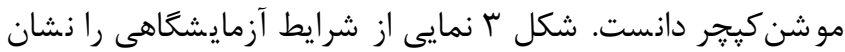

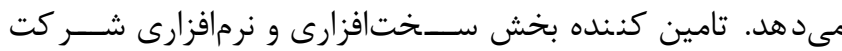

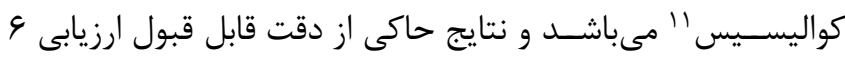

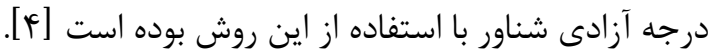

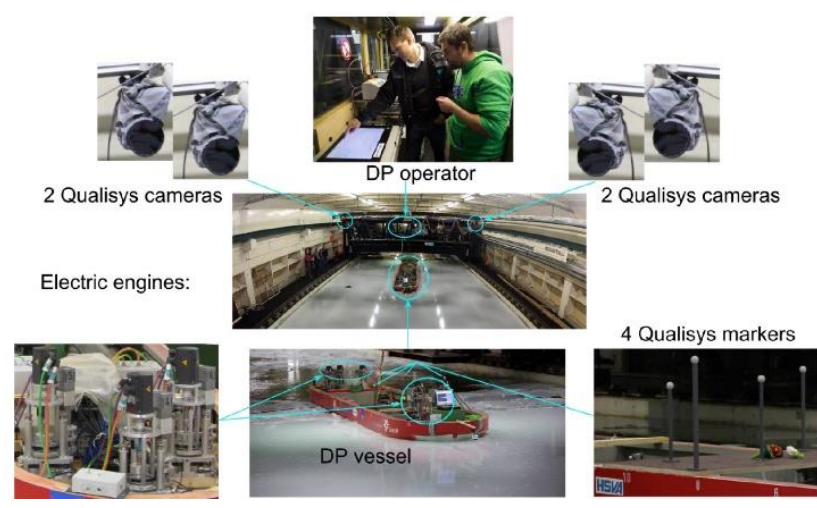

شكل ץ - جيدمان دوربينها و ماركر براى شبيه سازى حركت شناور

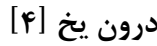

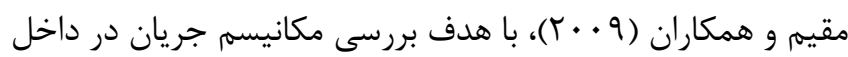
و خارج موجشـكن سـكويى شـكل يذير، دسـت به انجام آزمايش در فلوم موج مركز تحقيقات حفاظت خاك و آبخيزدارى وزارت جههاد

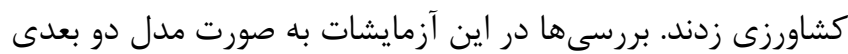

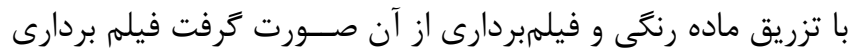
از الكوى جريان در داخل و خارج موج شـكن سـكويى شـكل يذير، تو سط دوربين انجام شده ا ست. به منظور تزريق مواد رنكى هنى هنَام

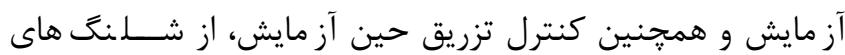
تزريق ماده رنغَى ا ستفاده گرديد. مـ شاهده گرديد كه با تزريق ماده سفيد رنگ، در طول پاييينروى موج؛ ق سمت عمده جريان تراو شى ماده

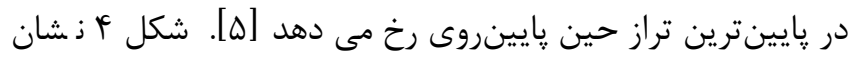
دهنده ادوات تصـوير بردارى حين آزمايش اسـت و شـكل هـ خروج

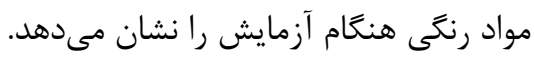
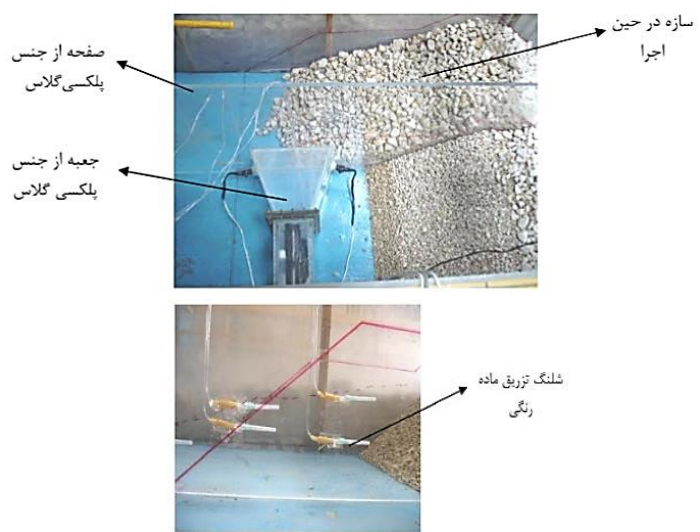

شكل F - موقعيت قراركَيرى دوربين ضد آب شده و نمايى از شلنَ هاى

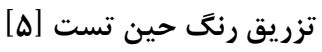




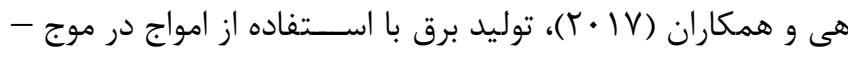

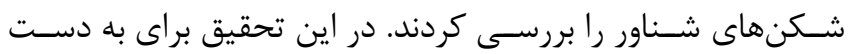

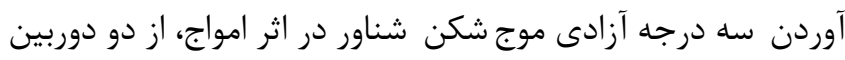

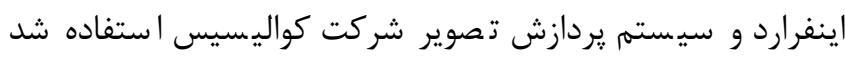

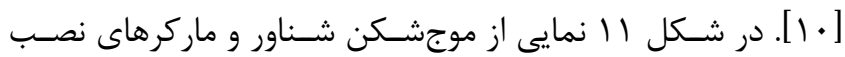

$$
\text { شده بر روى آن قابل مشاهده است. }
$$

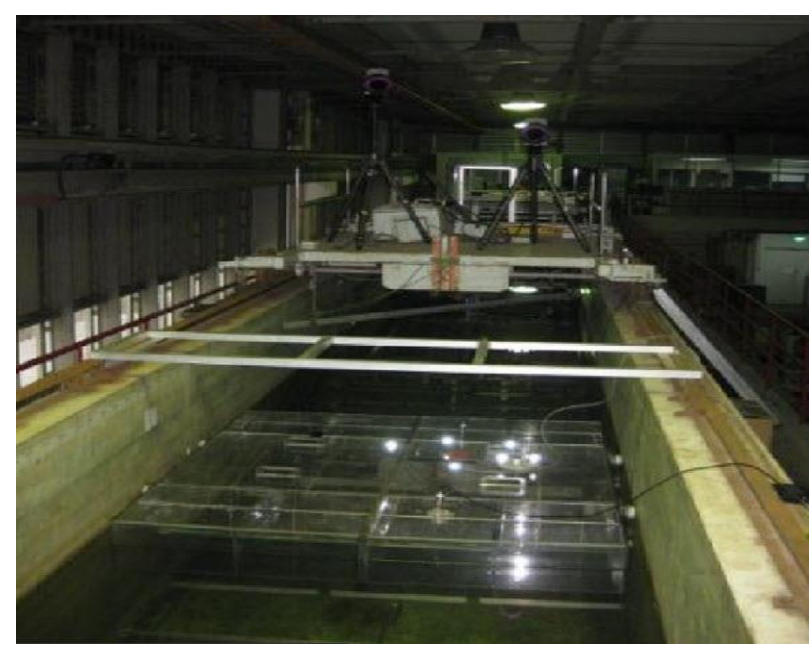

شكل |l - نمايى از موجشكن شناور به همراه ماركرها و دوربين اينفرارد [1.]

توجه به مطالعات انجام شـــده نشـــان مى دهد كه با اســــفاده از

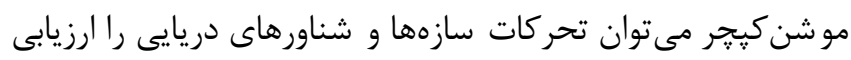

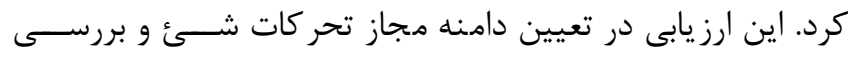
جابجايى آن در شـــايط آزمايشـــاهى مختلف كارئ كاربرد دارد. در اين مطالعه با بدست آوردن حركات انتقالى SPM تحت امواج منظم به

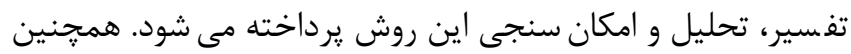

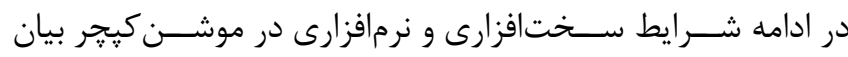
خواهد شد.

\section{r - روش شناسى مطالعات}

عكس ديجيتال را مىتوان با ســيخنال دوبعدى I(x,y) نمايش داد،

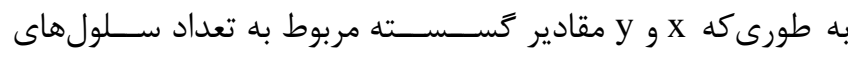
عمودى و افقى است كه از عكس حقيقى ساخته مى شود. هر سلول

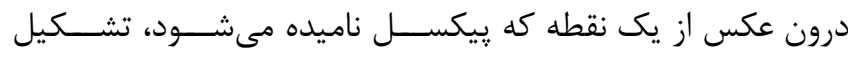

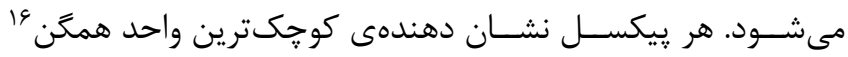
M عكس ديجيتال اسـت. وقتى كفته ميىشـود يك عكس ديجيتال ييك سل عر ضى و N ي ر N

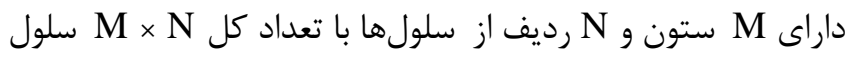
است. هر ييسكل درون عكس ديجيتال يك مقدار گسستهاى را ارائه مى دهد كه نشان دهنده مقدار روشنايى دريافت شده توسط سنسور دوربين است [11]]

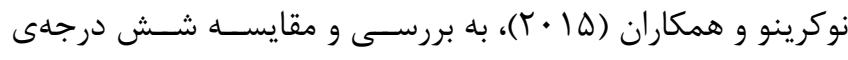

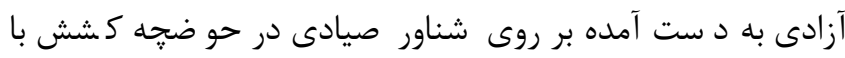
استفاده از سه دوربين يرداختند. در اين آزمايش از دوربين سونى و و دون

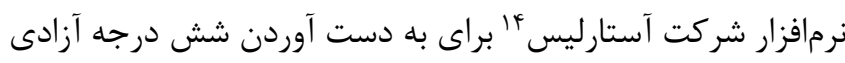

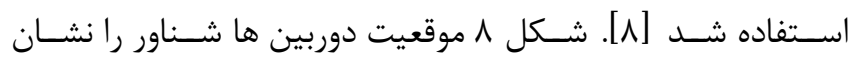

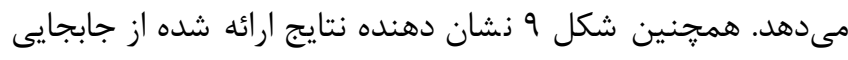

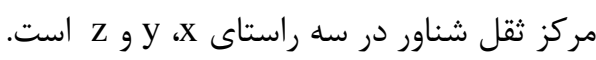

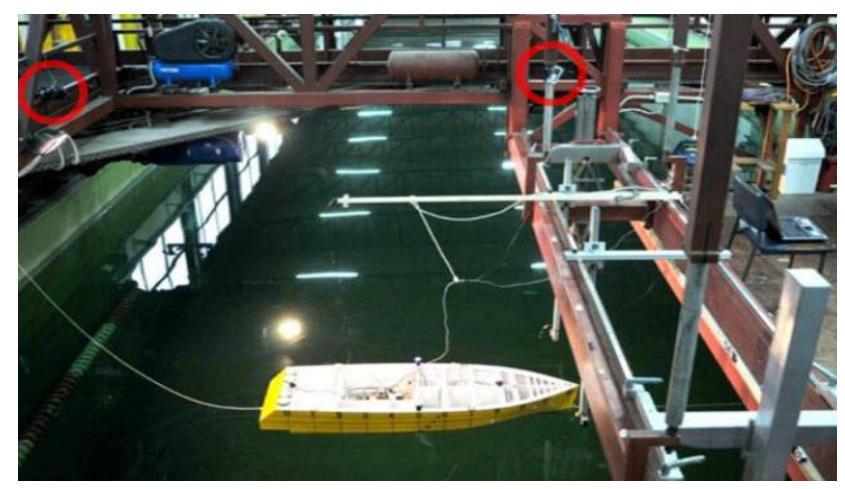

شكل^ - قراركيرى دوربين ها نسبت به شناور در آزمايش Nocerino و

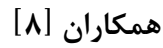

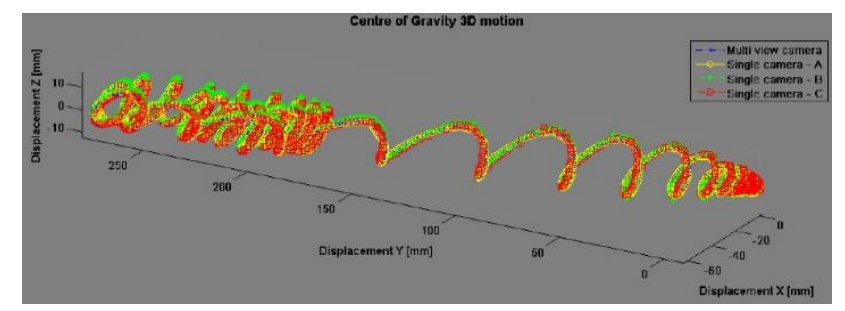

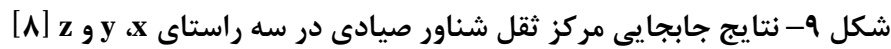

زاو و همكاران (ها • r)، به بررسى اندركنش دو جسم شناور نزديك به هم يرداختند. دو جسم صلب شناور با فاصله متغير از هم در برابر

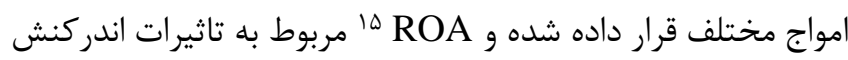

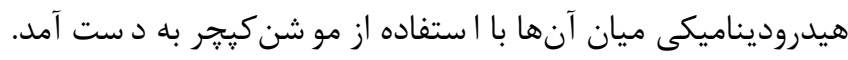

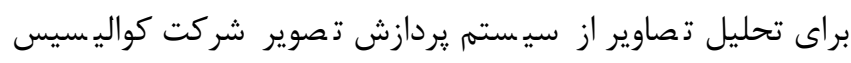

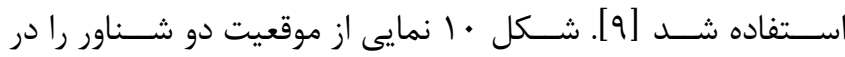
حوضجه كشش نشان مىدهد.

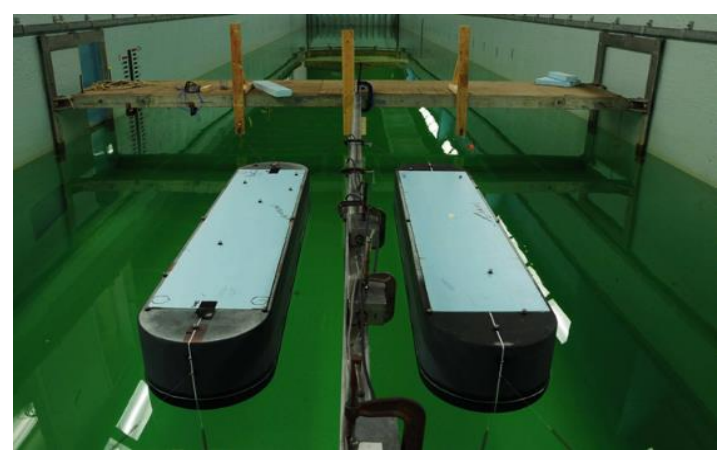

شكل •1 - نمايى از دو جسم صلب در نزديكى يكديكر دو حوضجه كشش [9] 
ماركر هاى قرار داده شـــده بر روى شـــئ، بايد در تمامى فر آيند

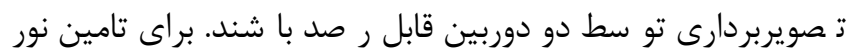
محيط فيلمبردارى از دو نورافكن استفاده شده است. تعداد نورافكن

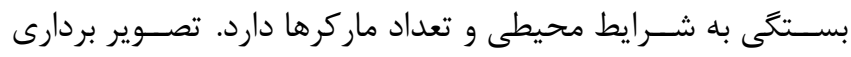
بو سيله دوربين Gopro (Hero5) انجام كرفته است. اين دوربين با باد

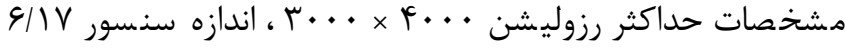

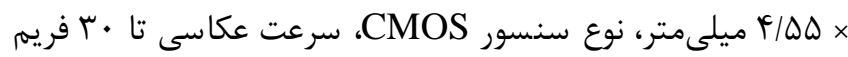

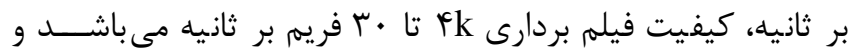
قابليت تثبيت كنندگى فيلهم را داراســت. در اين مطالعه به منظور

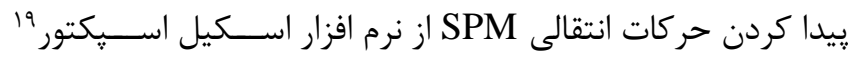
(Video4coach) حين آزمايش و دنبال كردن تحركات ماركرهاى ذصب شده

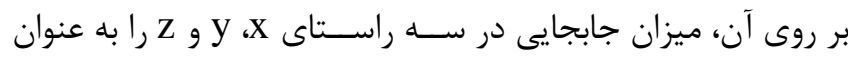

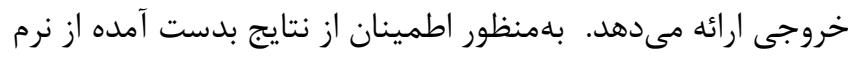

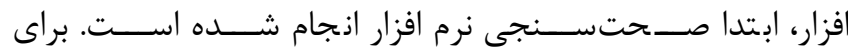
صحت سنجى نياز به ساخت المان كاليبراسيون است. در ادامه روند ساخت المان كاليبراسيون و صحتسنجى نرمافزار بار توضيح داده شده

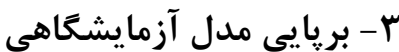
يردازش تصوير SPM در آزمايشاه ملى دريايى ايران با فلوم موج

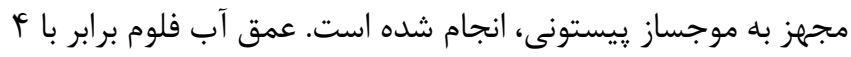

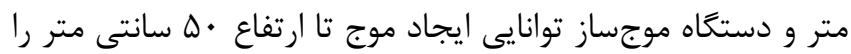

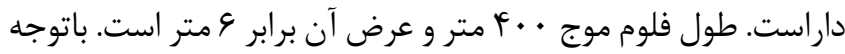

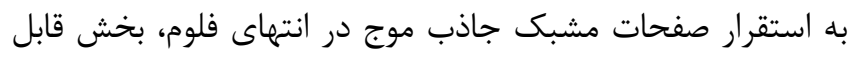

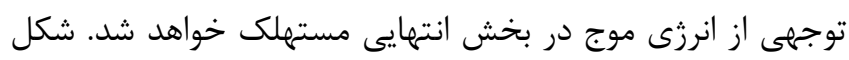

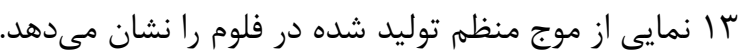

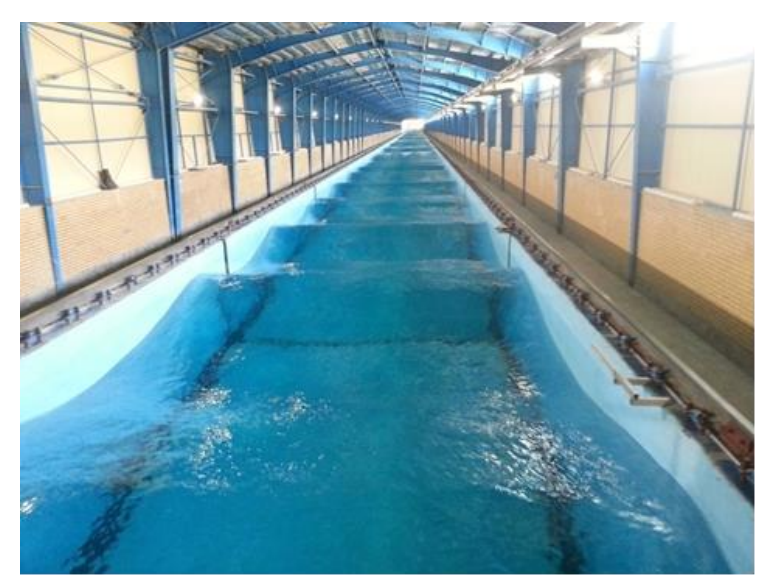

شكل سا - موج منظم توليد شده توسط موجساز در فلوم آزمايشعاهى

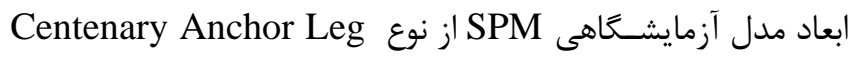
Mooring (CALM)
براى تحليل حركت اجسـام، دنبال كردن و ييدا كردن شـش درجه

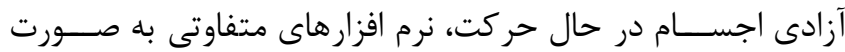
تجارى توليد شدهاند. هريك از شركتهاى ارائه دهنده اين خدمات

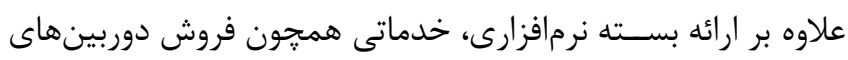

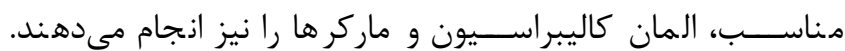
متداولترين روش مورد اسـتفاده در بازسـازى ســه بعدى تصـاوير،

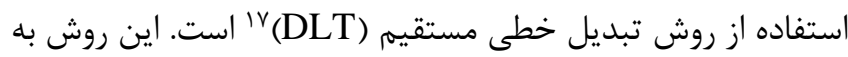

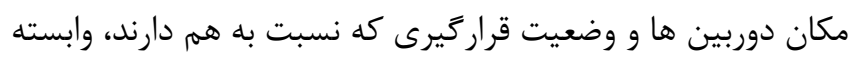

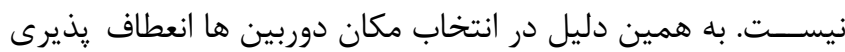
بالايى وجود دارد. همجنين اين روش رابطهى خطى بين تصــــاوير

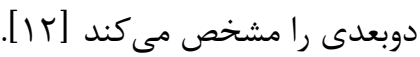
در اين مطالعه براى رديابى تحر كات SPM بر روى آن ســـه ماركر

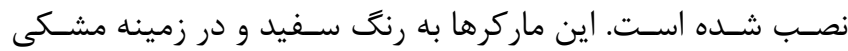

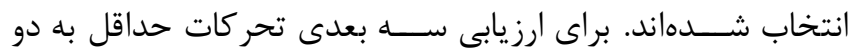

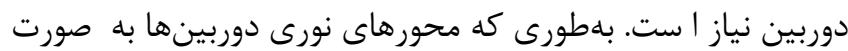

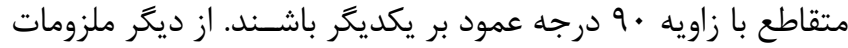
فيلمبردارى، همزمان سازى تصاوير است كه اين كار بوسيله كنترل

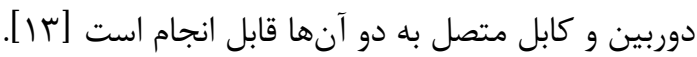
روش استاندراد براى تحليل سهبعدى، ثابت بودن دوربينها در طول

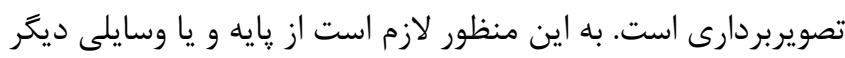

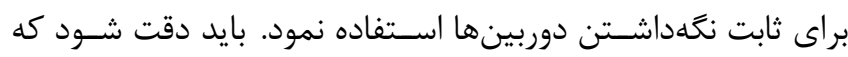

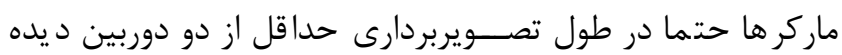

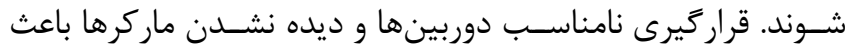

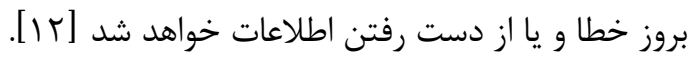

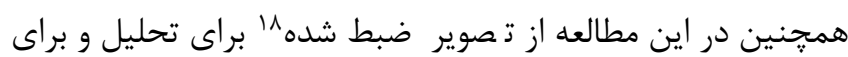

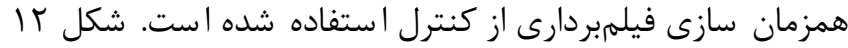
نشـان دهنده موقعيت دوربينها نسـبت به يكديكر و محدوده مورد بررسى است.

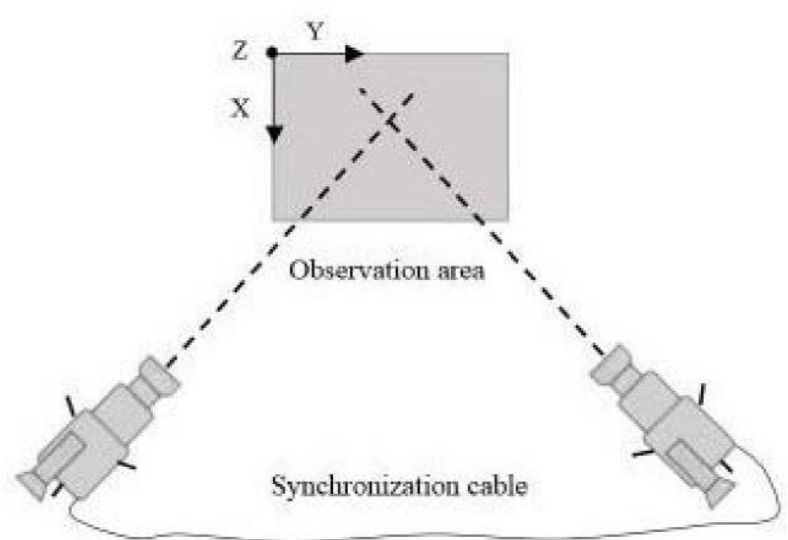

شكل rا - نمايى از نحوه قراركيرى دوربينها نسبت به يكديكر در

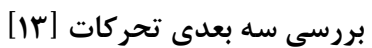




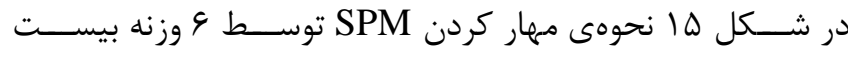

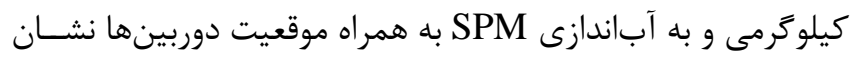

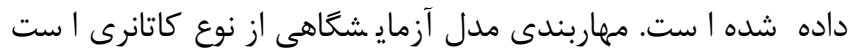

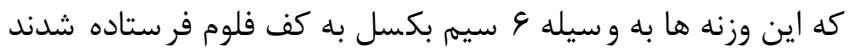

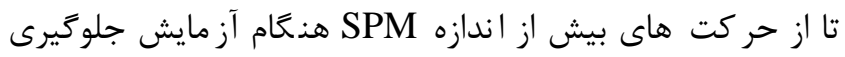

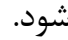

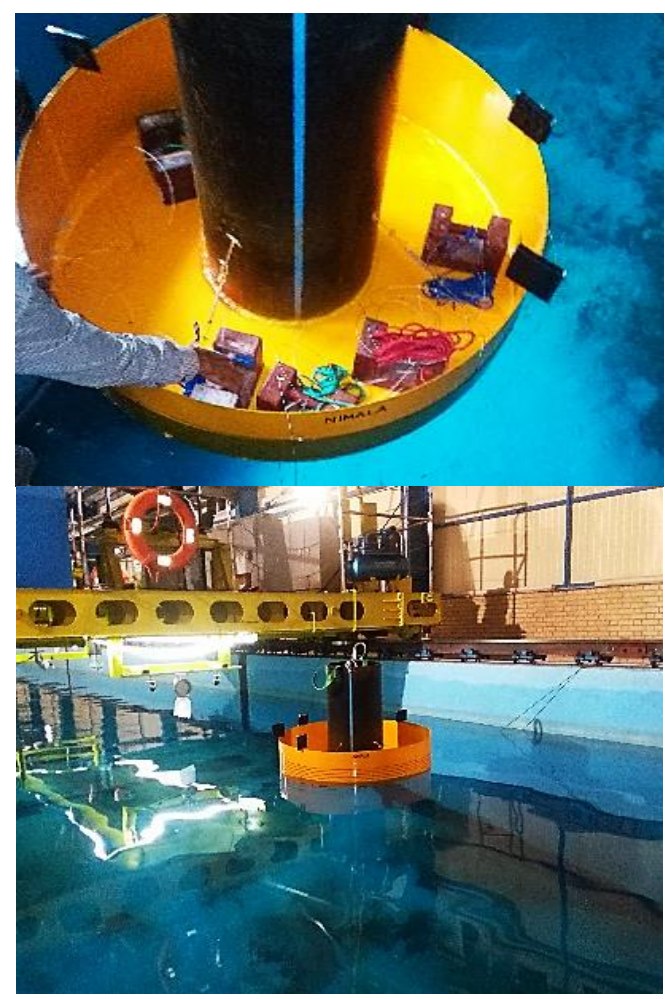

شكل هل - نحوهى مهار كردن SPM (تصوير بالا) و وضعيت قرارتيرى دوربينها نسبت به SPM (تصوير يايين)

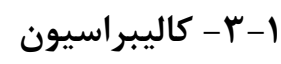

در اين بخش ابتدا به معرفى و بيان نحوه ساخت المان كاليبراسيون

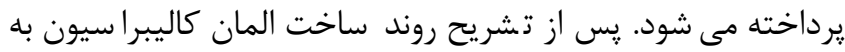

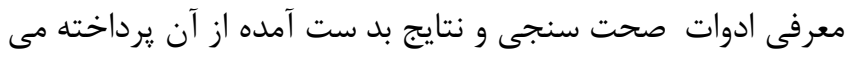

r-r- ساخت المان كاليبراسيون سه بعدى براى به دست آوردن رابطهاى بين مبدا مختصات دو بعدى تصاوير با ليان

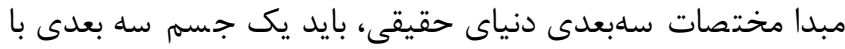

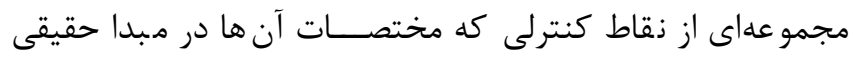
مشـــص اسـت، انتخاب شــوند. براى اين موضــوع معمولا از المان

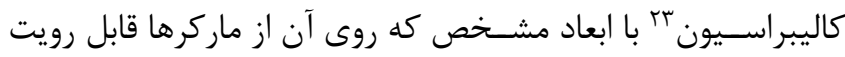

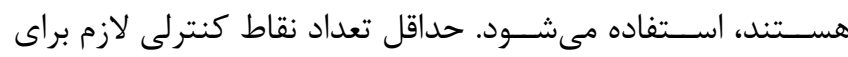
باز سازى مبدا مختصات سهبعدى حقيقى، 9 نقطه غير هم صفحه

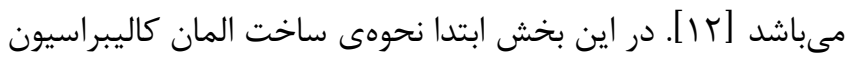

مخزن هَّ/• متر مى باشد. متريال ساخت SPM شامل ورق فولادى

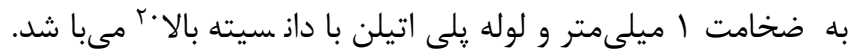

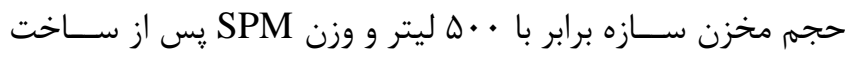

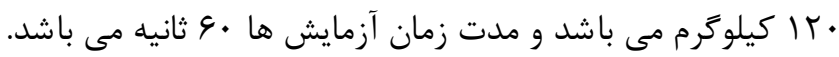

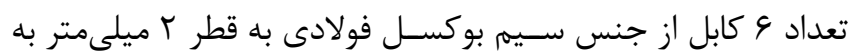
كف SPM (يايين تر از تراز آب) متصل شده است. طول هر كابل از

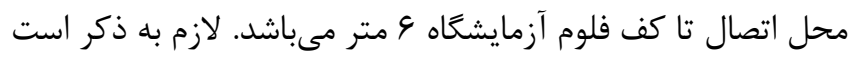

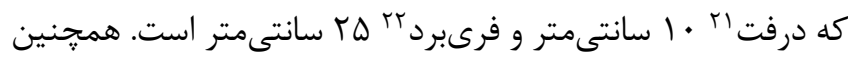

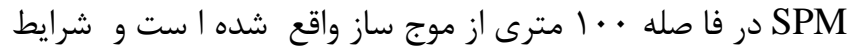
مربوط به موج آزمايش در جدول آل آورده شده است.

جدول 1 - مشخصات موج در شرايط آزمايشگاهى

\begin{tabular}{|c|c|c|}
\hline موج & ارتفاع موج أر] & يريود [s] \\
\hline منظم & $\cdot / 1 \Delta$ & . 199 \\
\hline
\end{tabular}

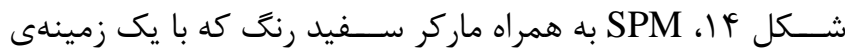
مشكى روى آن زصب شدهاند را نشان مى دهد. علت زصب ماركرها

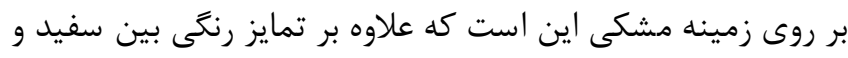

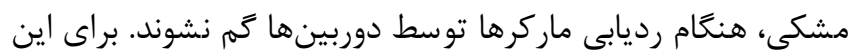
منظور از زينج ماركر سفيد با زمينه هشكى استفاده شده است. لازم

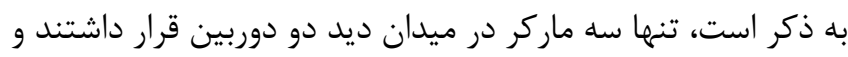

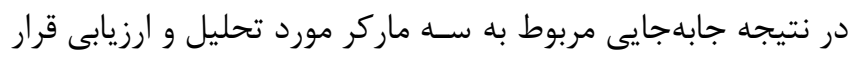
كرفته است.
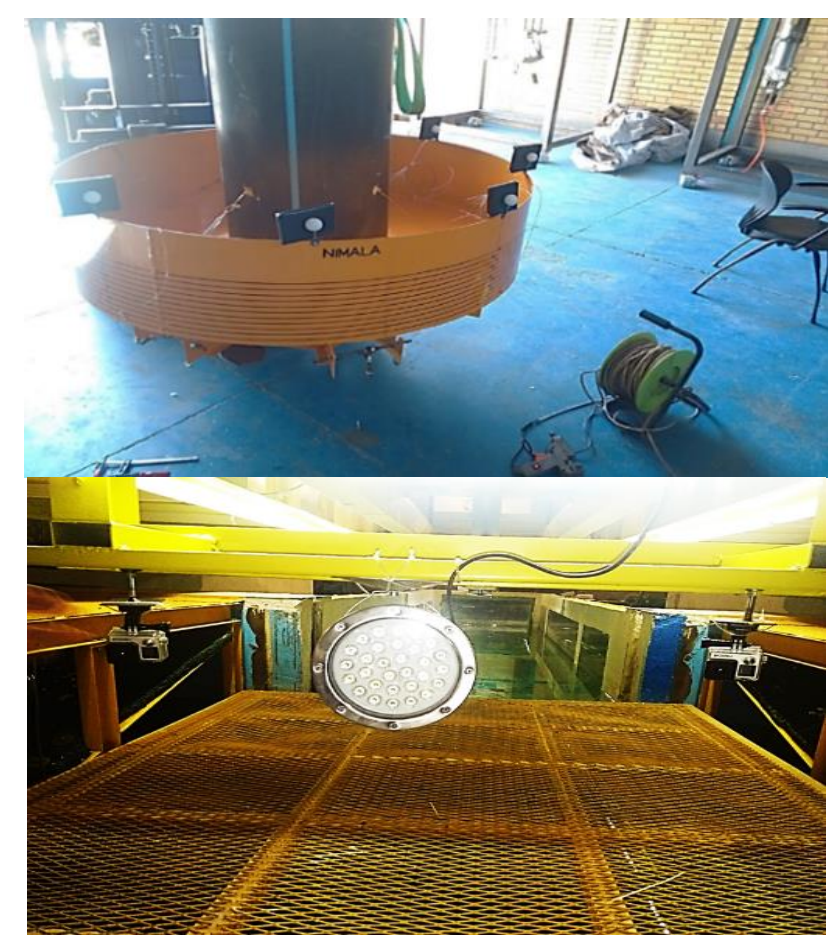

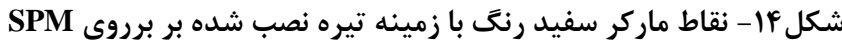

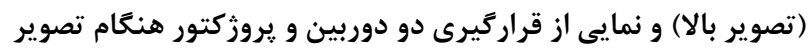
بردارى از SPM (تصوير يايين) 


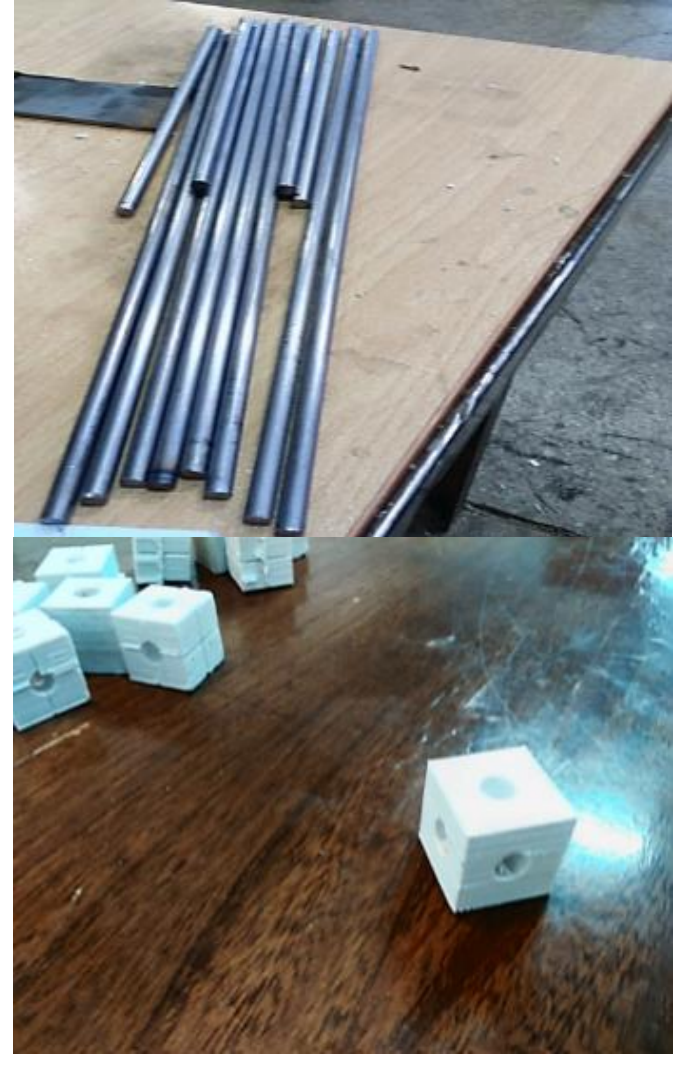

شكل IV - نمايى از ميله هاى مورد استفاده در ساخت المان صحت

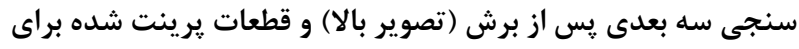

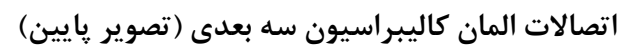

براى اتصـال ميلهها به صـورت قائم در محل مكعب ابتدا يك تخته ابزار جوبى براى كونيا كردن ميلهها ساخته شد. همانطورى كه ده در

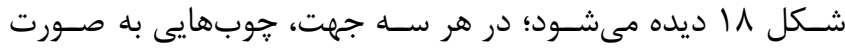

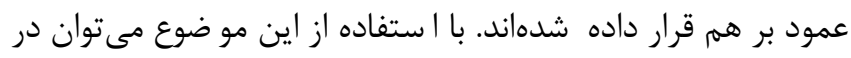

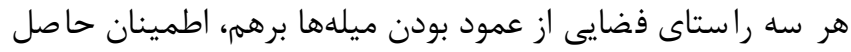

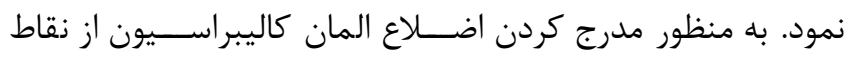

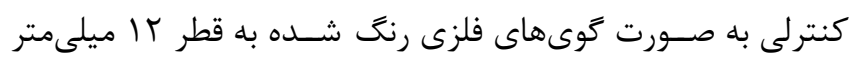

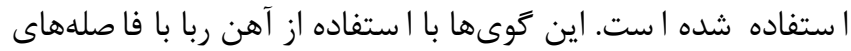

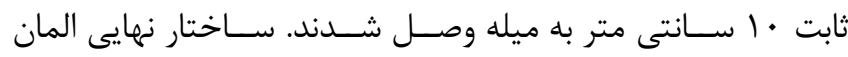
كاليبراسيون در شكل 9 ا نمايش داده شده است.

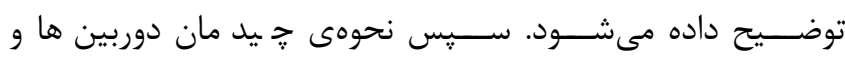
صحت سنجى نتايج يرداخته شده است. هرجقدر المان كاليبراسيون

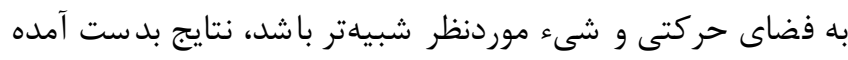

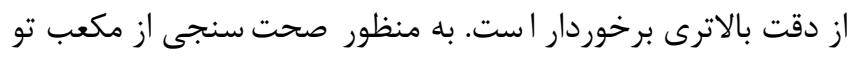

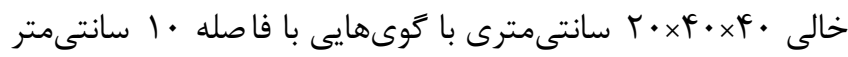

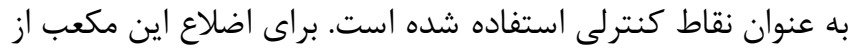

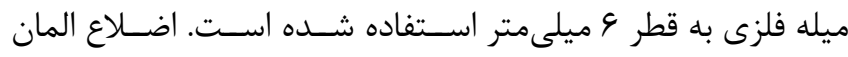

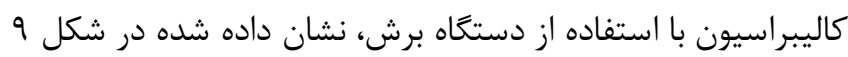

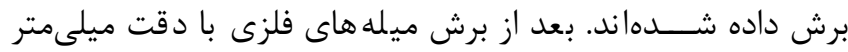
توسط اين دستخاه، نياز به وصل كردن اضلاع است. براى اتصال اين

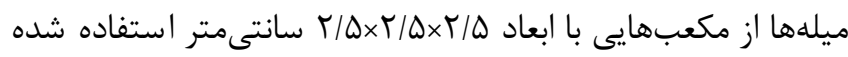

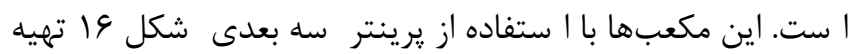

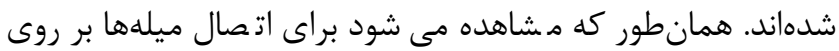

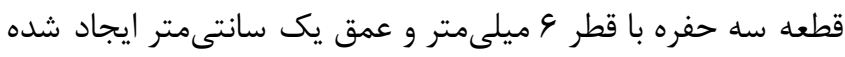

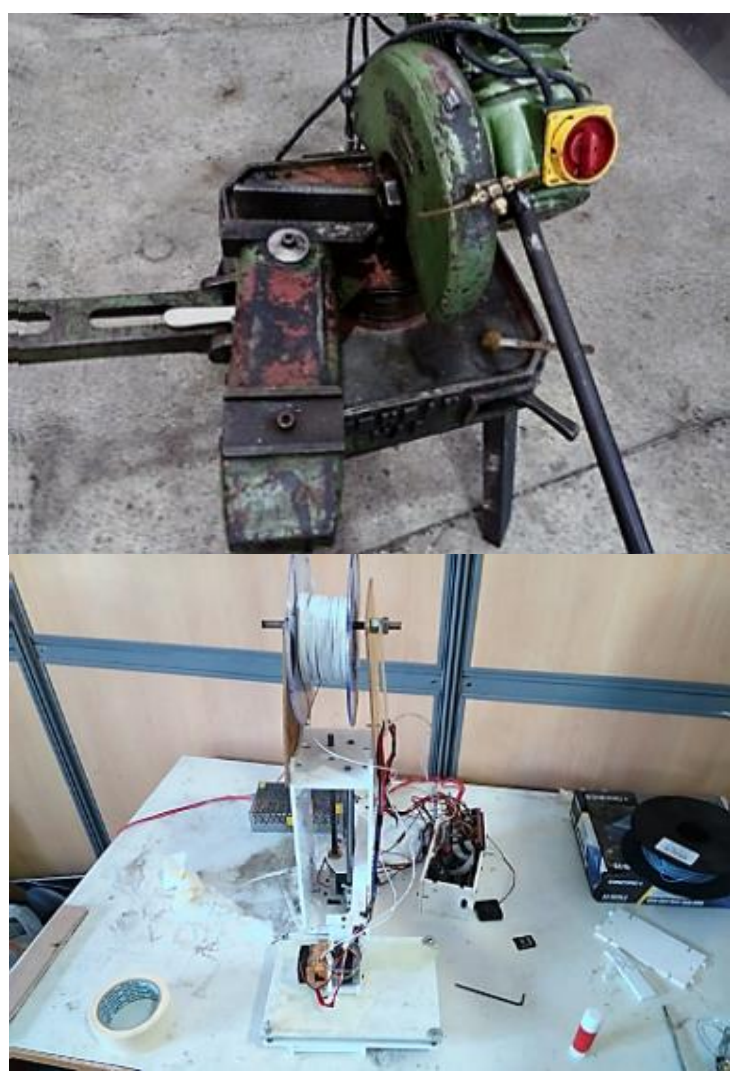

شكل 19 - دستخاه برش مورد استفاده براى برش ميله هاى المان

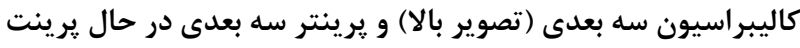
اتصالات اصلى المان كاليبراسيون سه بعدى (تصوير يايين)

همجنين در شكل VI امى توان ميلههاى برش داده شده به همراه اتصالات تهيه شده را مشاهده كرد. 
تمام ويزگى ها و يارامترهاى دو دوربين عيناً مشــابه هم هســتـند. همجنين مشخصات فيلمبردارى براى هر دو دوربين شامل رزولوشن

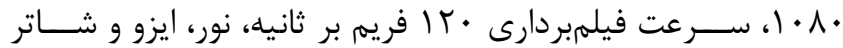

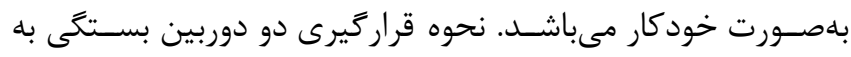

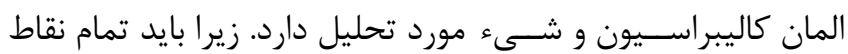

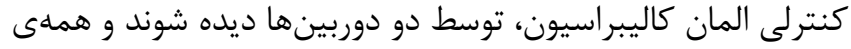

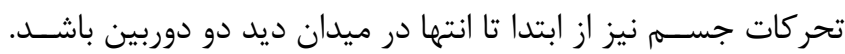

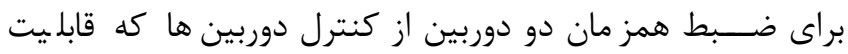

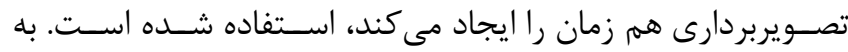
منظور ايجاد روشــنايى كافى هنكام فيلهبردارى از ســــهـ يروزكتور

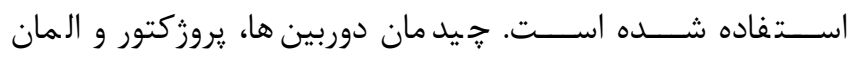
كاليبراسيون در شكل • r نشان داده شده است.

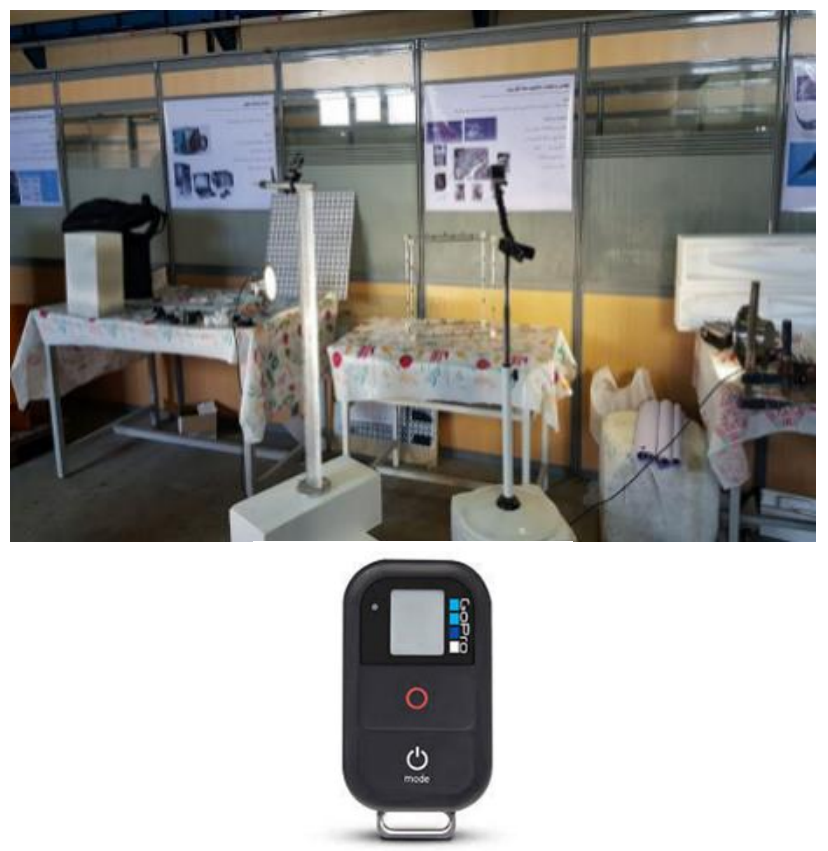

شكل •r- تصوير بردارى از المان كاليبراسيون سه بعدى در فر آيند

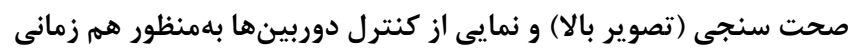
در تصوير بردارى (تصوير هإيين)

همانطور كه در شكل • † مـ شهود ا ست، دوربين ها با ا ستفاده از

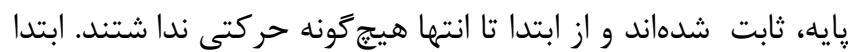

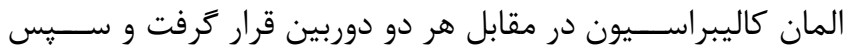

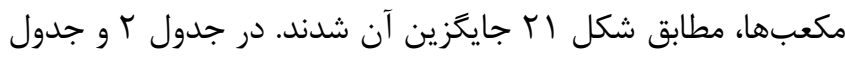

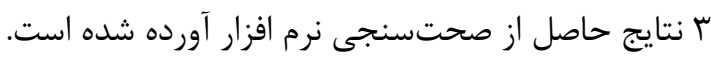

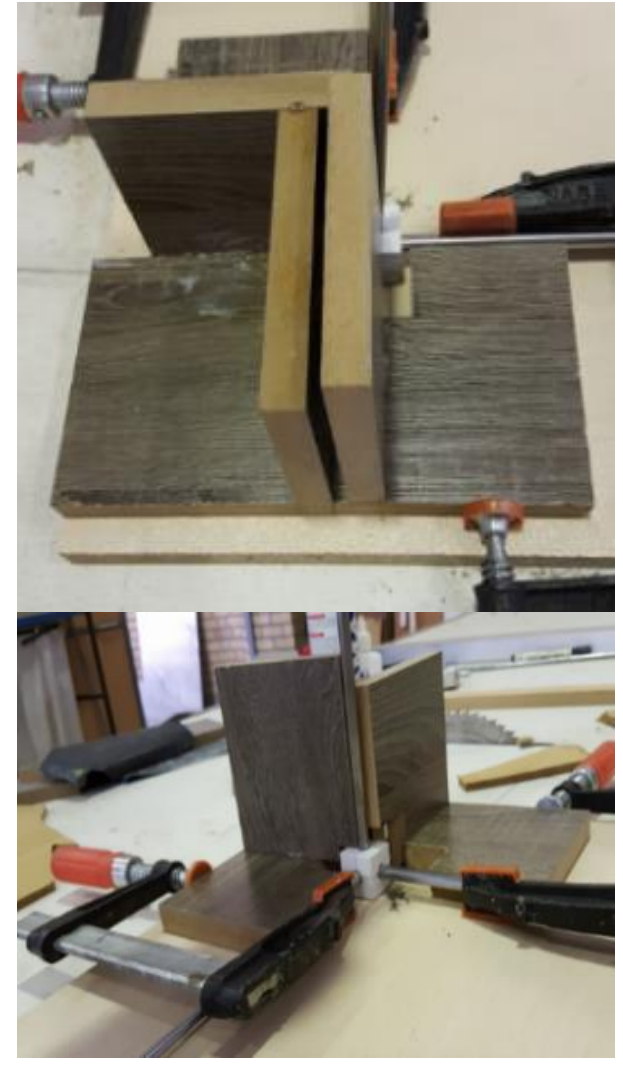

شكل 1 | - ابزار ساخته شده براى گونيا كردن ميله هاى المان

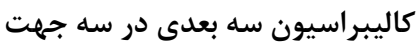

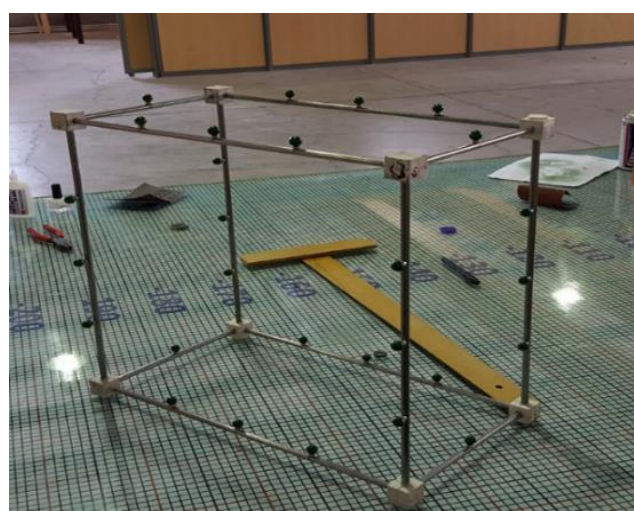

شكل 19 - ساختار نهايى المان كاليبراسيون سه بعدى به همراه كوى هاى آهنربايى رنت شده

r-r- صحت سنجى

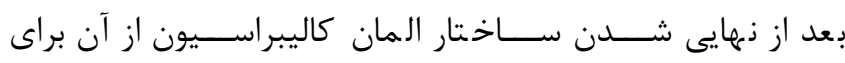

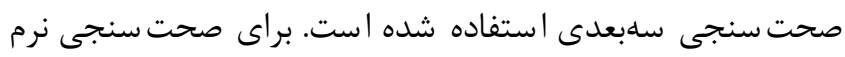

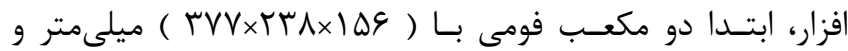

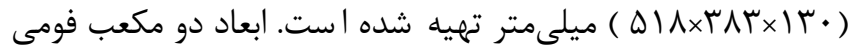

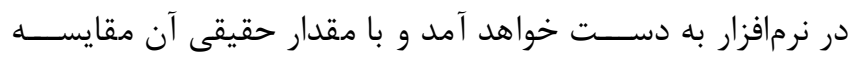

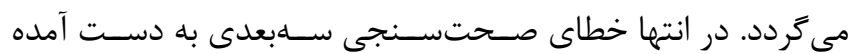
است. در ادامه نحوهى خيدمان، ارائه شده است.

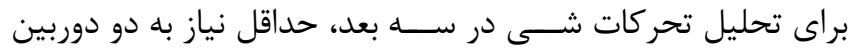

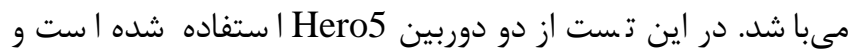




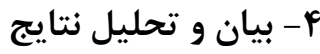

با قراردادن ســهـ ماركر بر روى SPM كه در تمام طول آزمايش توســط دو دوربين قابل رديابى هســتـند، به بيان نتايج يرداخته مى شود. در اين مطالعه به اختصار از سه حرف اول Right (راست)

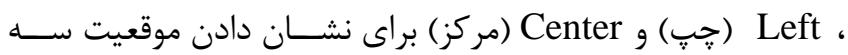

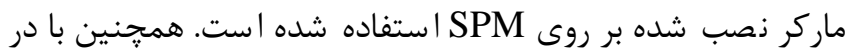
نظر گيرى موج منظم براى انجام آزمايشها به دليل تكرار شد سيكل

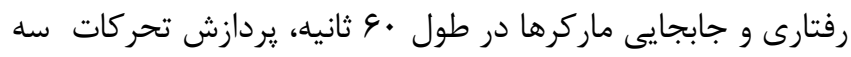

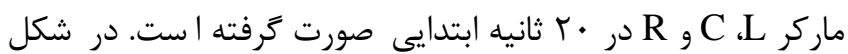

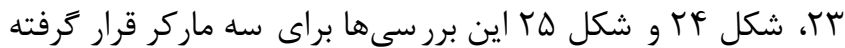

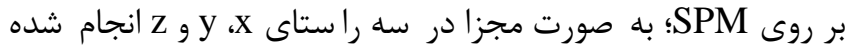

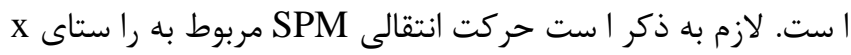
در راسـتاى طول فلوم؛ معرف Surge، د در راسـتاى عرضسى فلوم

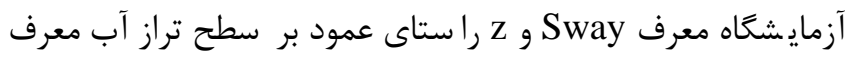
Heave روى SPM است.

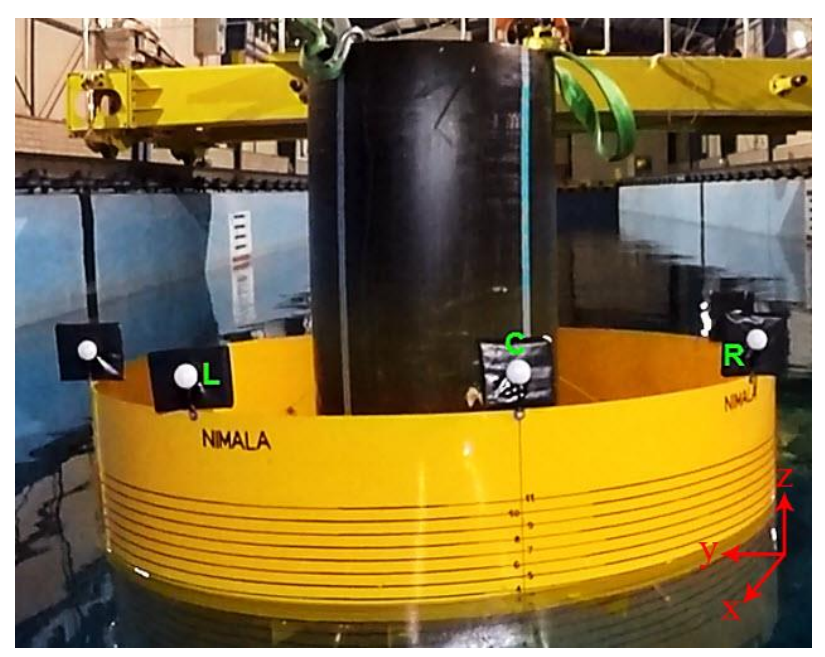

شكل r - - نامكذارى ماركرهاى بر روى SPM جهت تحليل تحركات

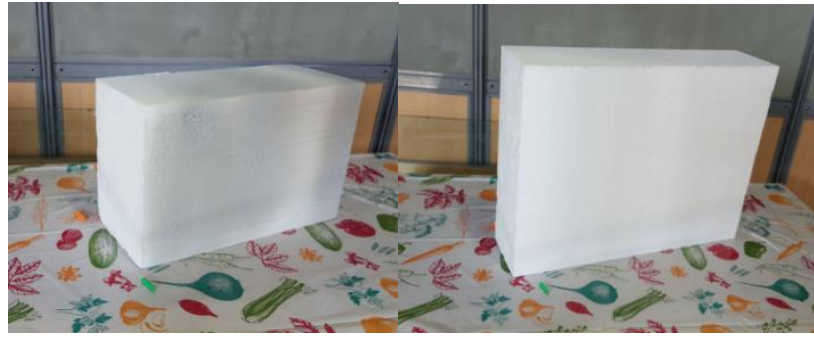

شكل آ - نمايیى از مكعب فومى بزرگت (سمت راست) و مكعب فومى كوجى (سمت جي)

جدول r - نتايج صحت سنجى و خطاى مربوط به آن در مكعب كوجى

\begin{tabular}{|c|c|c|c|c|}
\hline راستا & حقيقى] مقدار & تحليلى[mm] & خطا] & خطاى نسبى] \\
\hline $\mathrm{x}$ & rVV & TVF/QT & $r / F$ & $\cdot 19 \Delta$ \\
\hline $\mathrm{y}$ & ז & TMY/TH & $r / V$ & $1 / \Delta \Lambda$ \\
\hline Z & 109 & $|\Delta T /| \Delta$ & $\Gamma / \wedge \Delta$ & $r / F G$ \\
\hline
\end{tabular}

جدول ץ - نتايج صحت سنجى و خطاى مربوط به آن در مكعب بزرى

\begin{tabular}{|c|c|c|c|c|}
\hline راستا & حقيقى] مقدار & تحليلى[mm] مقدار & خطا][mm] & خطاى نسبى [درصد] \\
\hline $\mathrm{x}$ & 011 & $\Delta T I / I F$ & $r / \mathcal{F}$ & .199 \\
\hline $\mathrm{y}$ & rᄉr & $r \wedge F / \& \Delta$ & $1 / 1$ & $\cdot / 4 \wedge$ \\
\hline $\mathrm{z}$ & $\pi r$. & ITI/AT & $1 / f$ & $1 / f$ \\
\hline
\end{tabular}

همانكونه كه در جداول ب و F ديده مىشــود بيشترين خطا در

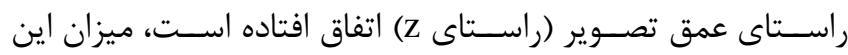
خطاى نسبى \& \&/F درصد است. اين راستا مربوط به مكعب كوجك،

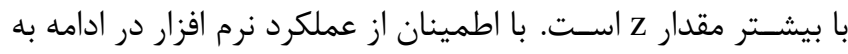
بررسى تحركات SPM در اثر موج منظه يرداخته مىشود.

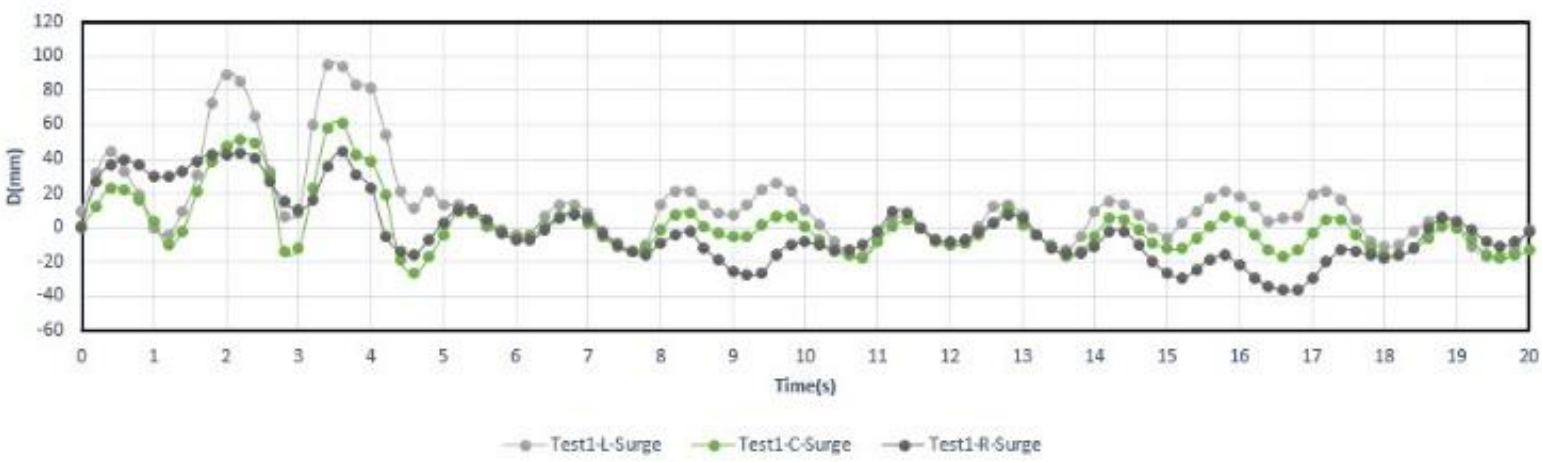

شكل rrre 


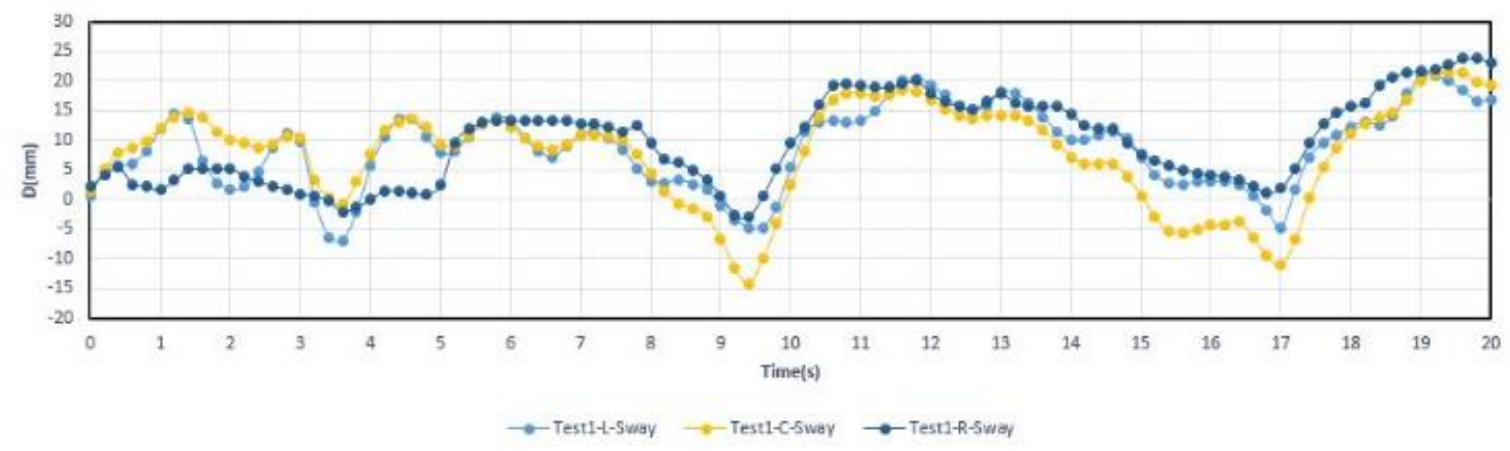

شكل TF جابجاييى ماركر L-C-R در موقعيت Sway

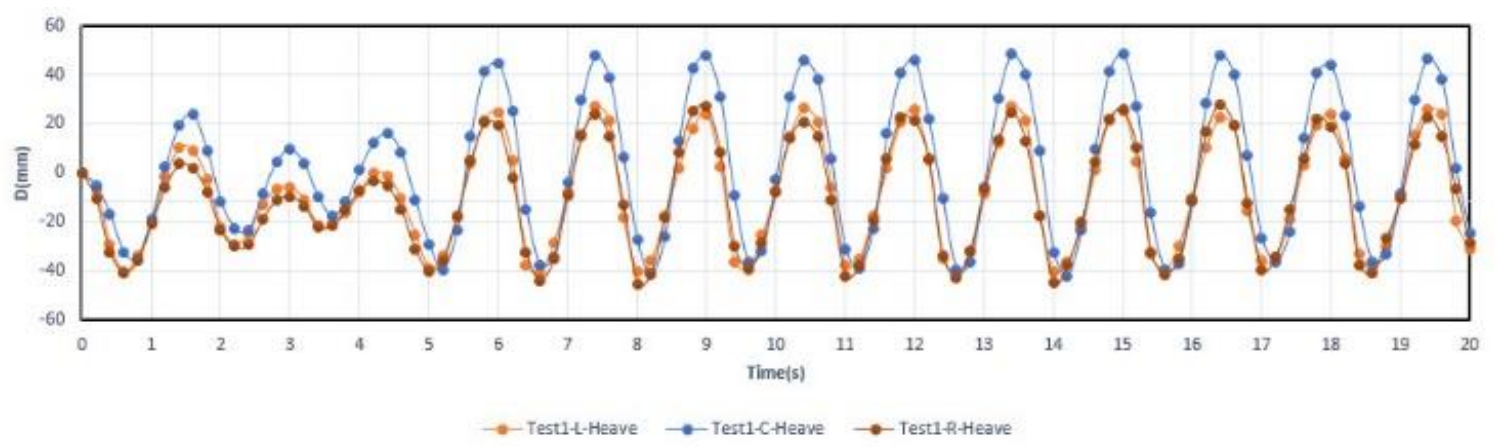

شكل Dr - جابجايى ماركر L-C-R در موقعيت Heave

R و شود و باعث افزايش مقادير Surge در ماركر هاى SMP

شود. همجنين بيشترين ميزان جابهجايى مربوط به Sway و Heave

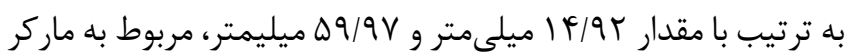
مى باشد. شكل צr C در ه ثانيه ابتدايى آزمايش اول است. مشاهده مىشود كه از

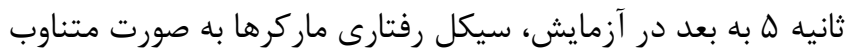

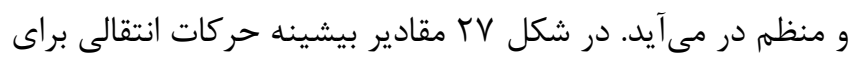
سه ماركر آورده شده است.

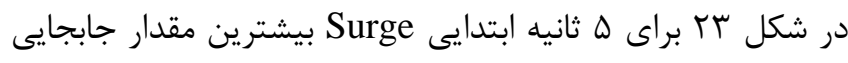

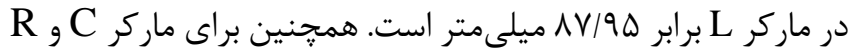

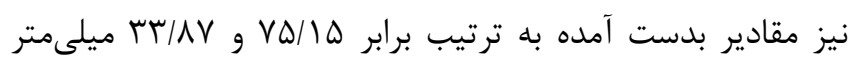

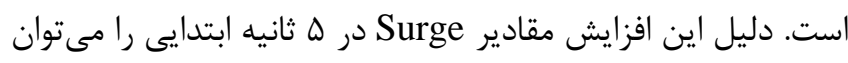
برخود جبهه موج با SPM دانست. به نحوى كه بيشترين تاثير

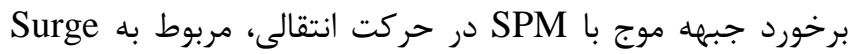
است. به دليل استوانهاى بودن مقطع SPM، در لحظه برخورد جبههه

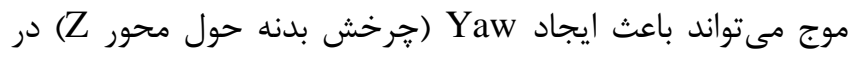

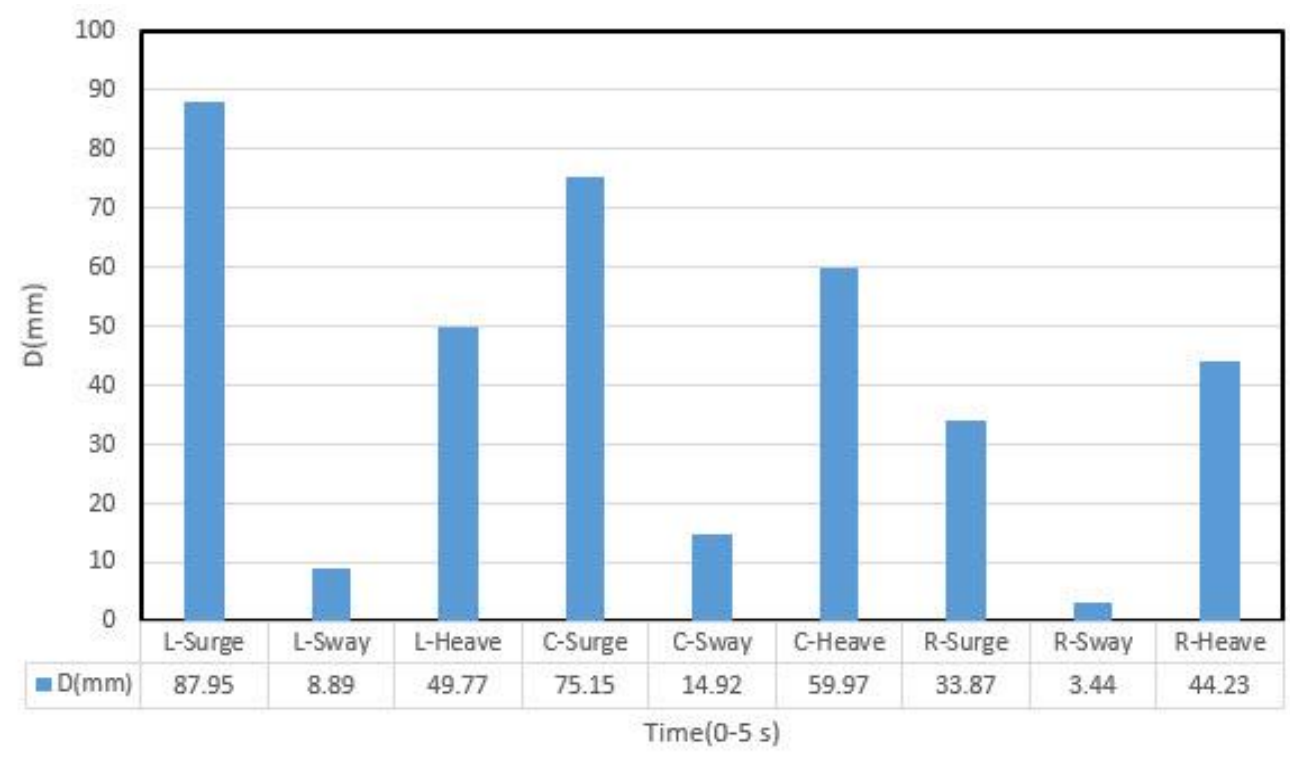

شكل \&ץ - مقادير بيشينه حركات انتقالى SPM در ه ثانيه ابتدايى آزمايش اول 


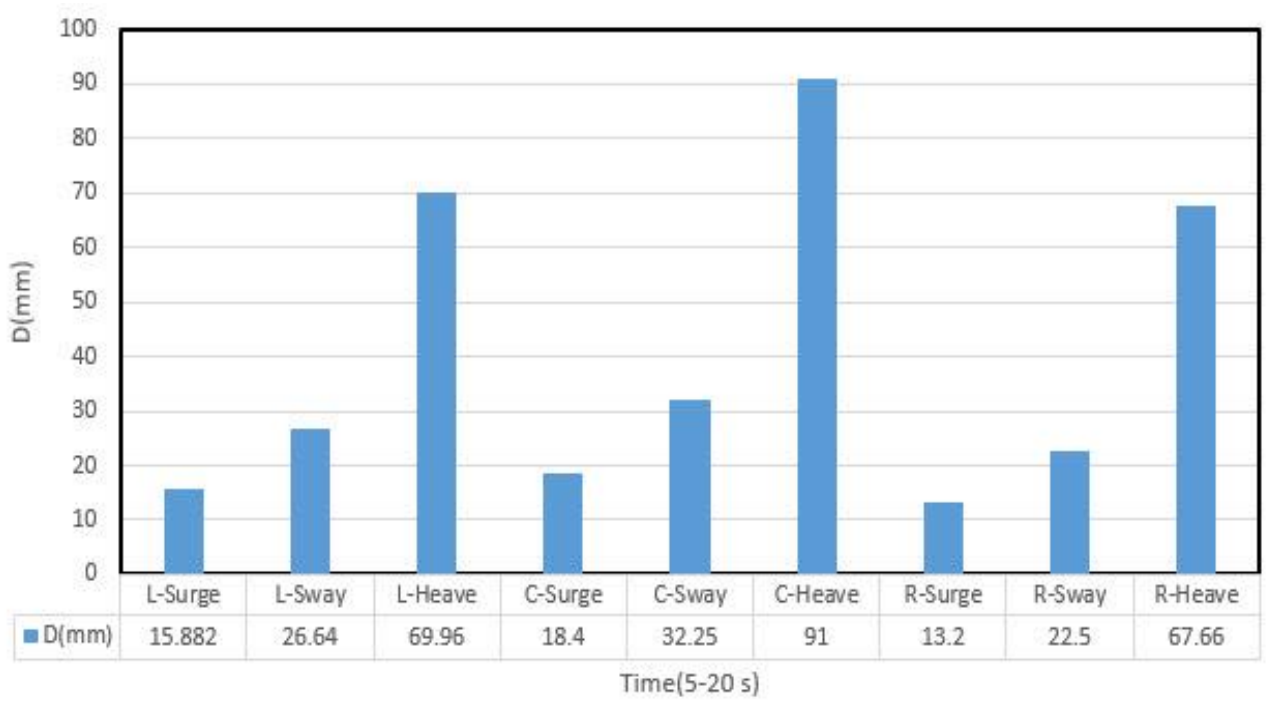

شكل VV - مقادير بيشينه حركات انتقالى SPM از ثانيه ه تا +r

\section{9- و تقدير و تشكر}

تمامى تســتهاى آزمايشـــاهى در آزمايشـــاه ملى دريايى ايران (شهداى خليج فارس - NIMALA ) صورت گرفته است. همجنين

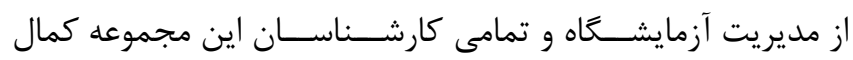

$$
\text { سياس و تشكر به عمل آورده مىشود. }
$$

1- Global Positioning Systems

2- Image Processing

3- Single Point Mooring

4- Infrared

5- Radio Frequency Energy

6- Vibration

7- Magnetism

8- Motion Capture

9- Tracking

10- Real Time

11- Qualisys

12- Riser

13- Vortex-Induced Vibration

14- Australis (Photometrix)

15- Response Amplitude Operators

16- Homogeneous

17- Direct Linear Transform

18- Offline

19- Skill Spector

20- High Density Polyethylene (HDPE)

21- Draft

22- Freeboard

23- Calibration Frame

$$
\text { - منابع - V }
$$

1. Pinkster, J. A., \& Remery, G. F. M., (1975), The role of model tests in the design of single point mooring
بيشـــترين حر كات انتقالى مربوط به ماركر C اســــ اين ماركر بيشترين جابهجايى را در Heave با ميزان الو ميليمتر داشته است. همجنين در Surge و Sway به ترتيب ميليمتر جابه جا شده است.

$$
\text { ه- نتيجه كيرى }
$$

در اين مطالعه به منظور بررســى تحركات SPM در اثر موج منظمم

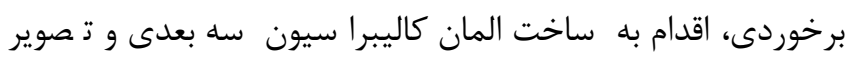
بردارى از سه ماركر به وسيله دو دوربين شده است. با تفاسير عنوان

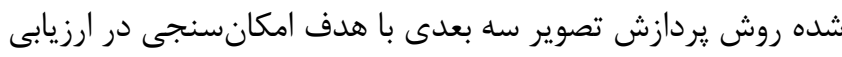

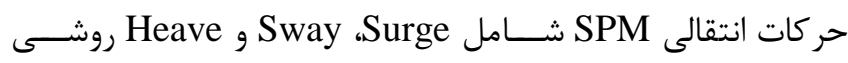

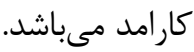

در ه ثانيه ابتدايى با برخورد موج منظم با SPM حر كت

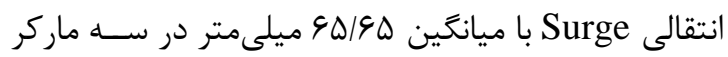

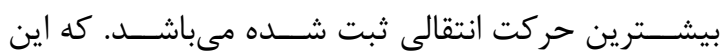

$$
\text { افزايش به دليل برخورد اوليه جبهله موج تابشى است. }
$$
با توجه به نتايج به دسـت آمده از تحليل تحركات مربوط

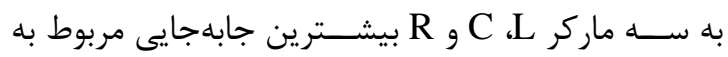

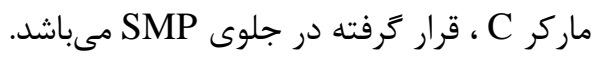

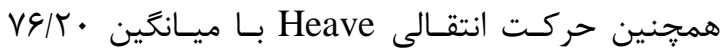
ميلىمتر بيشــترين جابهجايى را به خود اختصــاص داده است.

لازم به ذكر از بين حركات انتقالى شامل Sway ،Surge

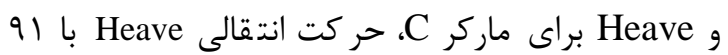
ميلى متر بيشـترين جابهجايى ثبت شـده در سـه ماركر را

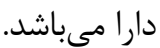


In Videometrics, Range Imaging, and Applications XIII (Vol. 9528, p. 95280K). International Society for Optics and Photonics.

9. Zhou, Q., Liu, M., Peng, H., \& Qiu, W., (2015), Experimental studies of hydrodynamic interaction of two bodies in waves. In ASME 2015 34th International Conference on Ocean, Offshore and Arctic Engineering (pp. V011T12A011-V011T12A011). American Society of Mechanical Engineers.

10. He, F., Leng, J., \& Zhao, X., (2017), An experimental investigation into the wave power extraction of a floating box-type breakwater with dual pneumatic chambers. Applied Ocean Research, 67, p. 21-30.

11. Rodríguez, J. L. R., (2017), Segmentation of molars in noisy pantomograms using digital image processing techniques.

12. Payton, C., \& Bartlett, R. (Eds.)., (2007), Biomechanical evaluation of movement in sport and exercise: the British Association of Sport and Exercise Sciences guide. Routledge.

13. Polak, E., Kulasa, J., VencesBrito, A., Castro, M. A., \& Fernandes, O., (2016), Motion analysis systems as optimization training tools in combat sports and martial arts. Revista de Artes Marciales Asiáticas, 10(2), p. 105-123. terminals. In Offshore Technology Conference. Offshore Technology Conference.

2. Van Bruggen, T., (2018), Mooring Line Failure Detection of a Single Point Mooring System: a ModelBased Approach.

3. Guerra-Filho, G., (2005), Optical Motion Capture: Theory and Implementation. RITA, 12(2), p. 61-90.

4. Kerkeni, S., Dal Santo, X., Doucy, O., Jochmann, P., Haase, A., Metrikin, I., ... \& Moslet, P. O., (2014), DYPIC project: Technological and scientific progress opening new perspectives. In OTC Arctic Technology Conference. Offshore Technology Conference.

5. Moghim, M. N., (2009), Experimental study of hydraulic stability of reshaping berm breakwaters (Doctoral dissertation, $\mathrm{PhD}$ thesis, Tarbiat Modares University). (In Persian).

6. Tofa, M. M. B., Maimun, A., Ahmed, Y. M., Jamei, S., \& Abyn, H., (2013), Two Degree of Freedom Vortex Induced Vibration Tests of a Riser Model Using Spring Bars. Applied Mechanics and Materials, 465, 1339.

7. Yang, Y. S., Yang, C. M., \& Huang, C. W., (2015), Thin crack observation in a reinforced concrete bridge pier test using image processing and analysis. Advances in Engineering Software, 83, p. 99108.

8. Nocerino, E., Menna, F., \& Remondino, F., (2015), Comparison between single and multi-camera view videogrammetry for estimating $6 D O F$ of a rigid body. 